\title{
Concentrations and source regions of light-absorbing particles in snow/ice in northern Pakistan and their impact on snow albedo
}

\author{
Chaman Gul ${ }^{1,2,3}$, Siva Praveen Puppala ${ }^{2}$, Shichang Kang ${ }^{1,3,4}$, Bhupesh Adhikary ${ }^{2}$, Yulan Zhang ${ }^{1}$, Shaukat Ali ${ }^{5}$, \\ Yang $\mathbf{L i}^{3}$, and Xiaofei $\mathbf{L i}^{1}$ \\ ${ }^{1}$ State Key Laboratory of Cryosphere Science, Northwest Institute of Eco-Environment and Resources, \\ Chinese Academy of Sciences, Lanzhou, 73000, China \\ ${ }^{2}$ International Centre for Integrated Mountain Development (ICIMOD), G.P.O. Box 3226, Kathmandu, Nepal \\ ${ }^{3}$ University of Chinese Academy of Sciences, Beijing, China \\ ${ }^{4}$ CAS Center for Excellence in Tibetan Plateau Earth Sciences, Beijing, 100101, China \\ ${ }^{5}$ Global Change Impact Studies Centre (GCISC), Ministry of Climate Change, Islamabad, Pakistan
}

Correspondence: Shichang Kang (shichang.kang@1zb.ac.cn), Siva Praveen Puppala (sivapraveen.puppala@icimod.org) and Chaman Gul (chaman.gul@icimod.org, chaman@1zb.ac.cn)

Received: 20 July 2017 - Discussion started: 28 August 2017

Revised: 1 March 2018 - Accepted: 8 March 2018 - Published: 12 April 2018

\begin{abstract}
Black carbon (BC), water-insoluble organic carbon (OC), and mineral dust are important particles in snow and ice which significantly reduce albedo and accelerate melting. Surface snow and ice samples were collected from the Karakoram-Himalayan region of northern Pakistan during 2015 and 2016 in summer (six glaciers), autumn (two glaciers), and winter (six mountain valleys). The average BC concentration overall was $2130 \pm 1560 \mathrm{ng} \mathrm{g}^{-1}$ in summer samples, $2883 \pm 3439 \mathrm{ng} \mathrm{g}^{-1}$ in autumn samples, and $992 \pm 883 \mathrm{ng} \mathrm{g}^{-1}$ in winter samples. The average waterinsoluble OC concentration overall was $1839 \pm 1108 \mathrm{ng} \mathrm{g}^{-1}$ in summer samples, $1423 \pm 208 \mathrm{ng} \mathrm{g}^{-1}$ in autumn samples, and $1342 \pm 672 \mathrm{ng} \mathrm{g}^{-1}$ in winter samples. The overall concentration of BC, OC, and dust in aged snow samples collected during the summer campaign was higher than the concentration in ice samples. The values are relatively high compared to reports by others for the Himalayas and the Tibetan Plateau. This is probably the result of taking more representative samples at lower elevation where deposition is higher and the effects of ageing and enrichment are more marked. A reduction in snow albedo of $0.1-8.3 \%$ for fresh snow and $0.9-32.5 \%$ for aged snow was calculated for selected solar zenith angles during daytime using the Snow, Ice, and Aerosol Radiation (SNICAR) model. The daily mean albedo was reduced by $0.07-12.0 \%$. The calculated radiative forcing ranged from 0.16 to $43.45 \mathrm{~W} \mathrm{~m}^{-2}$ depending on snow
\end{abstract}

type, solar zenith angle, and location. The potential source regions of the deposited pollutants were identified using spatial variance in wind vector maps, emission inventories coupled with backward air trajectories, and simple region-tagged chemical transport modeling. Central, south, and west Asia were the major sources of pollutants during the sampling months, with only a small contribution from east Asia. Analysis based on the Weather Research and Forecasting (WRFSTEM) chemical transport model identified a significant contribution (more than $70 \%$ ) from south Asia at selected sites. Research into the presence and effect of pollutants in the glaciated areas of Pakistan is economically significant because the surface water resources in the country mainly depend on the rivers (the Indus and its tributaries) that flow from this glaciated area.

\section{Introduction}

Carbon is an essential component of atmospheric aerosols, where it appears in the form of black carbon (BC, also known as elemental carbon, EC), and organic carbon (OC). BC is emitted into the atmosphere from the incomplete combustion of carbon-based fuels (mainly fossil fuels and biomass) (Jacobson, 2004), while OC can be directly emitted into or formed in the atmosphere. After deposition on snow and ice 
surfaces, BC particles significantly reduce the snow albedo (hemispheric reflectance) in the visible part of the electromagnetic spectrum, cause snow albedo feedback (Doherty et al., 2013), enhance solar radiation absorption (Warren and Wiscombe, 1980), and accelerate snow melting (Hansen and Nazarenko, 2004). BC, both in air and deposited on snow, is important in net positive forcing of the climate. Clean snow is one of the most reflective natural surfaces on Earth at the ultraviolet and visible wavelengths, while $\mathrm{BC}$ is the most efficient light-absorbing species in the visible spectral range (Horvarth, 1993). With regard to $\mathrm{BC}, 1 \mathrm{ng} \mathrm{g}^{-1}$ has almost the same effect on albedo reduction as $100 \mathrm{ng} \mathrm{g}^{-1}$ mineral dust at $500 \mathrm{~nm}$ wavelength (Warren, 1982). However, the exact amount of albedo reduction also depends on the refractive index, grain size, solar zenith angle (SZA), snow density, dust particle size and concentration, particle morphology, surface roughness, snow depth, liquid water content, snow shape, and topography (Warren and Wiscombe, 1985). Albedo reduction usually results in the amplification of the energy absorbed by dirty snow (Painter et al., 2010). An albedo feedback is triggered and amplified by the deposition of impurities on the snow surface, which reduces snow albedo, thus accelerating melting and further reducing albedo (Doherty et al., 2013; Flanner et al., 2009). Albedo feedback is amplified by the presence of light-absorbing particles (Doherty et al., 2013). Studies conducted in Greenland showed that at visible wavelengths, $10 \mathrm{ng} \mathrm{g}^{-1}$ coarse-grained $\mathrm{BC}$ particles in aged snow and $40 \mathrm{ng} \mathrm{g}^{-1} \mathrm{BC}$ particles in new snow can reduce snow albedo by around 1 to $3 \%$ (Warren and Wiscombe, 1985).

Increased BC mass concentration and deposition on the Tibetan glaciers over the last 20 years (Xu et al., 2009) have played a significant role in rapid glacier melting in the region (Xu et al., 2012; Yao et al., 2012). A high concentration of aerosol has deposited on the snow surface and increased the BC content in snow over the southern edge of the Tibetan Plateau to the north of the Himalayas (Gertler et al., 2016). The southern slope of the Himalayas is relatively even more exposed to $\mathrm{BC}$ due to emissions from India and transport through southwesterly and westerly winds (Xu et al., 2009; Yasunari et al., 2010). BC deposited on snow in the Himalayan region induces an increase in net shortwave radiation at the snow surface with an annual mean of about 1 to $3 \mathrm{~W} \mathrm{~m}^{-2}$, producing an estimated $0.05-0.3{ }^{\circ} \mathrm{C}$ warming (Ménégoz et al., 2014). The deposition of anthropogenic BC has been observed to contribute significantly to the decrease in snow cover extent over recent decades (Déry et al., 2007) and a shortening of the duration of the snow cover season by several days (Ménégoz et al., 2013). The climate warming efficiency of BC in snow is greater than the warming efficiency of other anthropogenic pollutants, including carbon dioxide (Hansen et al., 2005). Another important characteristic of $\mathrm{BC}$ is its higher snowmelt efficiency. The snowmelt efficiency of BC in terms of snow cover fraction and snow water equivalent is larger than that induced by an increase in carbon dioxide (Qian et al., 2011). The annual snow albedo reduction effect due to $\mathrm{BC}$ outweighs the aerosol dimming effect (reduction in solar radiation reaching the surface) by a factor of about 6 over the global snow cover (Flanner et al., 2009).

At present, south and east Asia are considered to be the two largest $\mathrm{BC}$ emission regions in the world and are likely to remain so (Menon et al., 2010). BC transported from east Asia can be lifted high and moved towards the northeast during the summer monsoon season (Zhang et al., 2015; Cong et al., 2015; Lüthi et al., 2015), affecting the life of glaciers and snow-covered areas.

Research into the glaciers of the extended Himalayan region and Tibetan Plateau has prime importance because these glaciers act as a water storage tower for south and east Asia, and shrinking could affect the water resources for up to 1 billion people (Immerzeel et al., 2010). The glaciated area in northern Pakistan may be more exposed to BC effects than that in other regions because it can potentially receive emissions generated from both south and central Asia as well as from the Middle East. Meltwater coming from these glaciers flows into the river Indus, which has major economic importance for the people of Pakistan.

A number of authors have described the concentration and impacts of light-absorbing particles in the Tibetan glaciers (for example Qian et al., 2015; Wang et al., 2015; Zhang et al., 2017; Li et al., 2017; Niu et al., 2017). However, until now, no studies have been published relating to the concentration of light-absorbing aerosols in the surface snow and ice of northern Pakistan, and although several authors have investigated transport pathways over the Himalayan region (e.g., Babu et al., 2011 for the western trans-Himalayas; Lu et al., 2012 for the Tibetan Plateau and Himalayas), little is known about the potential sources and transport pathways of pollutants affecting the Pakistan area.

In this study, we looked at the concentration of lightabsorbing particles (BC, OC, dust) in snow and ice in northern Pakistan, their impact on snow albedo and radiative forcing, and the likely source regions. Albedo was estimated from the $\mathrm{BC}$ and dust concentrations identified in collected samples of snow and ice using the online snow albedo simulation Snow, Ice, and Aerosol Radiation (SNICAR) model (Flanner et al., 2009). Radiative forcing was calculated from the albedo reduction obtained from the SNICAR model together with the incident shortwave solar radiation obtained from the Santa Barbara DISORT Atmospheric Radiative Transfer (SBDART) model. The frequency distribution of aerosol subtypes (smoke, polluted continental, dust, and others) in the atmosphere over the study area was calculated for the snow and ice sampling periods using CloudAerosol Lidar and Infrared Pathfinder Satellite Observations (CALIPSO) satellite data from 2006 to 2014 as a further indication of the types of aerosol contributing to the observed deposition. The potential source regions of pollutants were identified using spatial variance in wind vector maps prepared using Modern-Era Retrospective analysis for Re- 
search and Applications, Version 2 (MERRA-2) reanalysis data, calculation of back air trajectories using the HYSPLIT4 (Hybrid Single Particle Lagrangian Integrated Trajectory) model, and a simple region-tagged chemical transport model (Weather Research and Forecast, WRF-STEM). The back air trajectories approach has been used in many studies to identify possible source regions for atmospheric and deposited BC (Zhang et al., 2013). Pollutant source regions identified using the different approaches were compared and the most likely source regions of the pollutants identified.

\section{Methodology}

\subsection{Study area}

The study area was located around $35.40^{\circ} \mathrm{N}, 74.38^{\circ} \mathrm{E}$ in the mountains and adjacent mountain valleys of the Karakoram and Himalayan region in northern Pakistan (Fig. 1). Snow and ice samples were collected in summer from six glaciers - Passu, Gulkin, Barpu, Mear, Sachin, and Henarche - and in autumn from Gulkin and Sachin (Fig. 1). The Passu and Gulkin glaciers are located very near the Karakoram highway connecting Pakistan with China, and there are a number of small villages (Passu, Hussaini, Gulmit, and others) close by. The Barpu and Mear glaciers are located very close to each other and around $3 \mathrm{~km}$ away from the residential area of the Hopar and Nagar valleys. There is a small city (Astore) near the Sachin glacier and some restaurants near its terminus (Muhammad and Tian, 2016). Winter snow samples were collected from mountain valleys near the Passu, Barpu, and Sachin glaciers and three other areas to the west with a number of small villages (Fig. 1). The average elevation of the selected glaciers was quite low compared to the elevation of the glaciers studied for BC, OC, and dust on the Tibetan Plateau by previous researchers. The mountains around the selected glaciers are mostly dry and rocky. The 10-year records (1999-2008) of the two nearby climate stations at Khunjerab $\left(36.83^{\circ} \mathrm{N}, 75.40^{\circ} \mathrm{E} ; 4730 \mathrm{~m}\right.$ a.s.l. $)$ and Naltar $\left(36.29^{\circ} \mathrm{N}, 74.12^{\circ} \mathrm{E}\right.$; $2858 \mathrm{~m}$ a.s.l.) show mean total annual precipitation values of 170 and $680 \mathrm{~mm}$, respectively. The daily average temperature during winter and the premonsoon showed an increasing trend between 1980 and 2014 (Gul et al., 2017). The study area is mostly exposed to the westerlies and emissions from south Asia. Most of the people in the region use wood for cooking and heating.

\subsection{Sample collection}

A total of 50 surface ice and 49 snow samples were collected from the glaciers in summer 2015 and 2016 (Passu - 15; Gulkin - 31; Barpu - 6; Mear - 8; Sachin - 35; Henarche -4 ) and 13 (total of ice and snow samples combined) in autumn 2016 (Gulkin - 7; Sachin - 6) at elevations ranging from 2569 to $3895 \mathrm{~m}$ a.s.l. (Fig. 1). Eighteen snow samples were collected in winter 2015 and 2016 from nearby mountain valleys at elevations of 1958 to $2698 \mathrm{~m}$ a.s.l.; the winter sampling region was divided into six sites (S1 to S6) based on geographical location and elevation (Fig. 1). Samples were collected using the "clean hands - dirty hands" principle (Fitzgerald, 1999). Ice samples were collected from the surface $(5 \mathrm{~cm}$ depth) at different points on the glaciers. The elevation difference between collection points on the same glacier ranged from 30 to $100 \mathrm{~m}$.

The samples were preserved in ultraclean plastic bags, allowed to melt in a temporary laboratory near the sampling location, and filtered through quartz filters immediately after melting. An electric vacuum pump was used to accelerate filtration. The melted snow/ice volume of the samples was measured using a graduated cylinder. Sampled filters were carefully packed inside petri slides marked with a unique code representing the sample.

The snow density of winter snow samples was measured using a balance, snow/ice grain sizes were observed with an accuracy of $0.02 \mathrm{~mm}$ using a hand lens $(25 \times)$ (Aoki et al., 2011), and snow shape was estimated using a snow card. In the models, we assumed external mixing of snow and aerosol particles and spherical snow grains. Snow grain size and snow texture were the largest sources of uncertainty in albedo reduction (Sect. 3.3). Qian et al. (2015) have summarized the sampling methods available for light-absorbing particles in snow and ice from different regions including the Arctic, the Tibetan Plateau, and midlatitude regions.

\subsection{Dust, $\mathrm{OC}$, and $\mathrm{BC}$ analysis}

Before analysis, sampled filters were allowed to dry in an oven for $24 \mathrm{~h}$ and then weighed using a microbalance. The dust mass on the filters was calculated from the mass difference in weight before and after sampling (Kaspari et al., 2014; Li et al., 2017).

There are many methods available for analyzing $\mathrm{BC}$ and OC. The three methods considered the most effective for measuring $\mathrm{BC}$ and water-insoluble $\mathrm{OC}$ concentrations in snow are thermal optical analysis, filter-based analysis, and single-particle soot photometer analysis (Ming et al., 2008). The thermal optical (filter-based) analysis method has been used by many researchers (e.g., Li et al., 2017) and was chosen for the study. This is an indirect method for measuring $\mathrm{BC}$ and OC on sampled filters; it follows Beer's law and uses the stepwise combustion of the particles deposited on quartz filters (Boparai et al., 2008), followed by the measurement of light transmission and/or reflectance of the filters. The BC and $\mathrm{OC}$ content in the collected samples was measured using a thermal optical Desert Research Institute (DRI) carbon analyzer, similar to the Interagency Monitoring of PROtected Visual Environments (IMPROVE) protocol (Cao et al., 2003). The temperature threshold applied to separate the two species is described in M. Wang et al. (2012). A few $(<10)$ filters had higher dust loads; for these the method was slightly modified using a $100 \%$ helium atmosphere and temperature plateau 


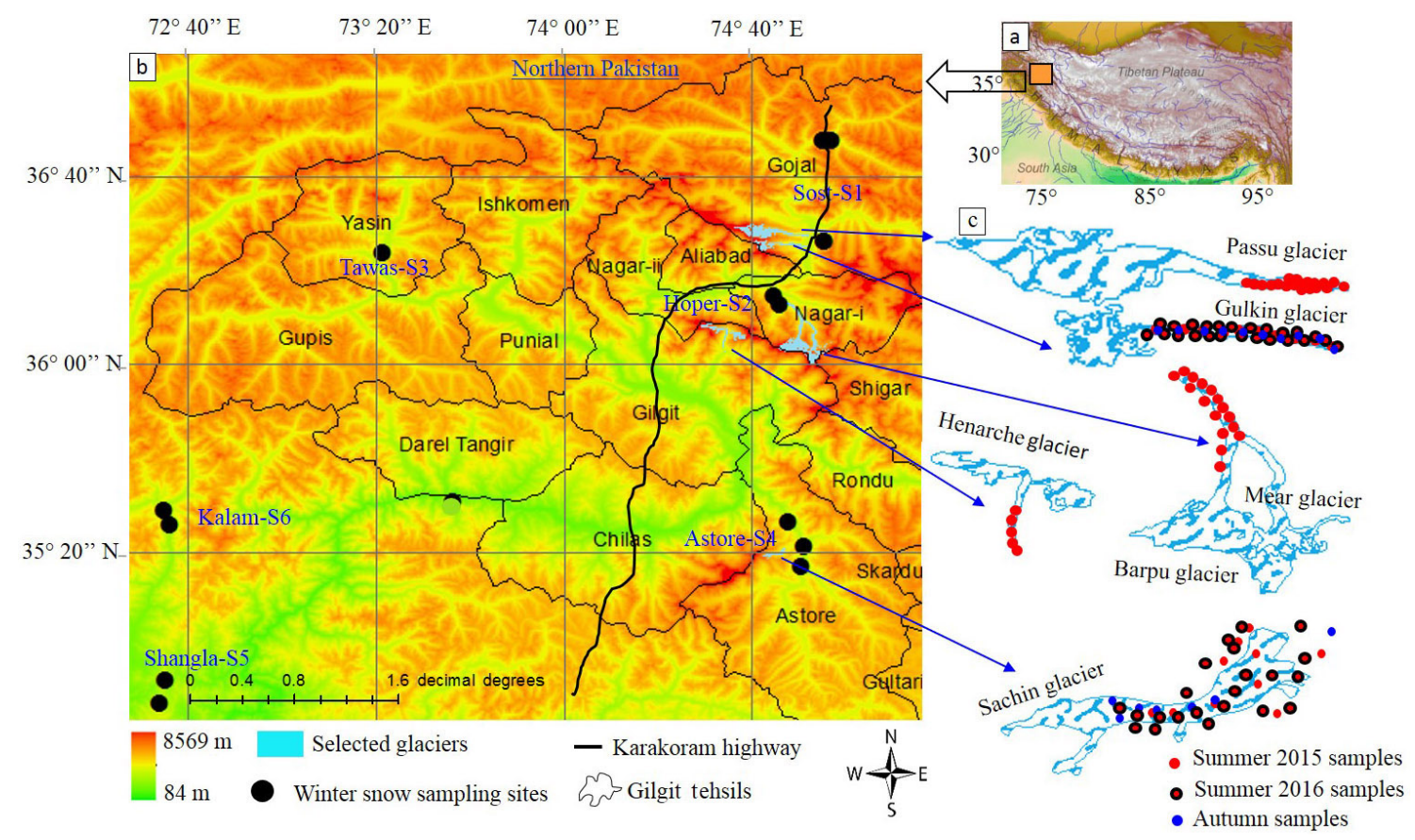

Figure 1. The study area and sampling sites: (a) Himalayan mountain range and Tibetan Plateau, (b) winter sampling sites (solid black circles), (c) glaciers selected for summer and autumn sampling.

$\left(550^{\circ} \mathrm{C}\right)$. A very few $(<5)$ samples with very dense dust concentrations were not properly analyzed by the instrument and were excluded from the results. The extremely high dust value of one sample from Passu (15 times the level in the next-highest sample), which had low values of other pollutants, was excluded as a probable error. In some cases, a single sample was analyzed two or three times to ensure accurate results were obtained.

The CALIPSO models also define multiple aerosol subtypes - clean continental, clean marine, dust, polluted continental, polluted dust, smoke, and other - using the $532 \mathrm{~nm}$ $(1064 \mathrm{~nm})$ extinction-to-backscatter ratio. The frequency of these different aerosol subtypes in the atmosphere over the study region was investigated using CALIPSO data for the same months in which ice and snow samples were collected, i.e., January, May, June, and December, over the period June 2006 to December 2014. The CALIPSO Level 2 lidar vertical feature mask data product describes the vertical and horizontal distribution of clouds and aerosol layers (downloaded from https://eosweb.larc.nasa.gov/project/ calipso/aerosol_profile_table, last access: May 2016). The aerosol subtypes were classified in the downloaded data using the observed backscatter strength and depolarization values. The details of the algorithm used for classification are given in Omar et al. (2009). The percentage contributions of individual aerosol subtypes were plotted using MATLAB (MathWorks, Inc.).
The frequencies of different subtypes were calculated along the specific paths followed by CALIPSO over the study region.

\subsection{Albedo simulations and estimation of radiative forcing}

Snow albedo was estimated for each of the 18 winter samples and the average calculated for samples at each of the sites (1 to 6). Albedo from two sites - S1 (Sost), which had the highest average concentration of BC and dust, and S6 (Kalam), which had the lowest average concentration of $\mathrm{BC}$ and dust - was further explored using the SNICAR model (Flanner et al., 2007). The aim was to quantify the effect of BC, dust, and mass absorption cross section (MAC) on albedo reduction. Sensitivity model experiments were carried out using various combinations of $\mathrm{BC}$, dust, and MAC values, while other parameters were kept constant (parameters for sites 1 and 6 shown in the Supplement, Table S1). Snow albedo was simulated for different daylight times, with the solar zenith angle (SZA) set in the range $57.0-88.9^{\circ}$ based on the position of the sun in the sky for the sampling date and locations. The daily mean was calculated from the mean of the albedo values simulated for 24 different SZA values (one per hour) and the daytime mean from the mean of the albedo values simulated for 10 SZA values (one per hour during daylight). The midlatitude winter clear-sky option was selected for surface spectral distribution. The parameters used for sensitivity analysis are shown in Table S1 in the Supplement. MAC val- 
ues of $7.5,11$, and $15 \mathrm{~m}^{2} \mathrm{~g}^{-1}$ were selected based on a literature review (Qu et al., 2014; Pandolfi et al., 2014). In order to reduce the uncertainty, the dust concentration in the samples was divided into four diameter classes (as per the model requirements): size $1(0.1-1.0 \mu \mathrm{m})$ was taken to be $2 \%$, size $2(1-2.5 \mu \mathrm{m})$ to be $13 \%$, size $3(2.5-5 \mu \mathrm{m})$ to be $31 \%$, and size $4(5-10 \mu \mathrm{m})$ to be $54 \%$ of total dust mass present in the sample, based on results published by others (Gillette et al., 1974; Mahowald et al., 2014). Radiative forcing (RF) was estimated for the same samples following Eq. (1):

$R F_{x}=R_{\text {in-short }} \cdot \Delta \alpha_{x}$,

where $R_{\text {in-short }}$ denotes incident shortwave solar radiation (daily mean), as measured by the SBDART model, and $\Delta \alpha_{x}$ denotes the daily mean reduction in albedo, as simulated by the SNICAR model.

\subsection{Source regions of pollutants}

Three methods were used to identify the potential source regions of pollutants found at the study site: wind maps, emissions inventory coupled with back trajectories, and a regiontagged chemical transport modeling analysis.

Wind vector maps were prepared using MERRA-2 reanalysis data (available from the National Aeronautics and Space Administration (NASA): https://gmao.gsfc.nasa.gov/ reanalysis/MERRA-2/docs/, last access: December 2017). The $U$ and $V$ wind components were combined into a matrix around the study area for each individual month and then plotted against latitude-longitude values to show the spatial variance of monthly wind stress at $850 \mathrm{mb}$ using arrows to indicate the direction and intensity of wind.

Air trajectories were calculated backwards from the sampling sites (S1: $36.40^{\circ} \mathrm{N}, 74.50^{\circ} \mathrm{E} ; \mathrm{S} 6: 35.46^{\circ} \mathrm{N}, 72.54^{\circ} \mathrm{E}$ ) to identify potential source regions for the pollutants using the web version of the HYSPLIT-4 model (Draxler and Hess, 1998). The HYSPLIT-4 model has been used by others to compute air mass trajectories to identify possible source regions (Ming et al., 2009; Zhang et al., 2013). Reanalysis meteorological data from the same source as the wind data (https://www.esrl.noaa.gov/psd/data, last access: November 2016) were used as input data in the HYSPLIT model for May, June, and December 2015 and January 2016. HYSPLIT was run in a 7-day backward trajectory mode with trajectories initiating every $6 \mathrm{~h}(0,6,12$, and 18$)$ on a daily basis from 4 May to 19 June 2015 ( 77 days during summer) and from 1 December 2015 to 31 January 2016 (62 during winter). The HYSPLIT model results were combined with Representative Concentration Pathway (RCP) emission data for 2010 (available from http://sedac.ipcc-data.org/ddc/ar5_scenario_ process/RCPs.html, last access: November 2016; data file $<$ RCPs_anthro_BC_2005-2100_95371.nc $>$ ) to identify the source location. This comprises emission pathways starting from an identical base year (2000) for multiple pollutants, including $\mathrm{BC}$ and $\mathrm{OC}$; the file description indicates that the inventory includes biomass burning sources. The RCP inventory has the same emissions sectors as the Hemispheric Transport Air Pollution (HTAP) emission inventory used in the modeling approach for identifying source regions (see below), including fuel combustion, industry, agriculture, and livestock, but the HTAP inventory has a higher resolution $\left(0.1 \times 0.1^{\circ}\right)$ than the RCP inventory $\left(0.5 \times 0.5^{\circ}\right)$. Lamarque et al. (2010) give a more detailed discussion of the inventory and sectors (12) used in the base year calibration of the RCP. Monthly CALIPSO satellite-based extinction data from 2006 to 2014 were used to calculate the vertical profile for aerosol extinction over the study region. The CALIPSO extinction profile was constructed for selected months in 2006 to 2014 - May and June for summer and December and January for winter (Fig. S1). The exponential equation $X=(\log (10.46)-\log (Y)) / 10.29$, where $Y$ is the vertical height of individual trajectories in kilometers and $X$ indicates the extinction against the height of trajectories, was used to calculate the extinction profile for the trajectory heights. The normalized extinction profile was obtained by assuming that surface extinction equals 1 (Fig. S1).

The WRF-STEM model was used as a third approach for identifying the origin (source regions) of air masses carrying pollutants. The WRF-STEM model uses region-tagged carbon monoxide (CO) tracers for many regions in the world to identify geographical areas contributing to observed pollutants (Adhikary et al., 2010). Region-tagged CO tracers are used as a standard air quality modeling tool in various regional and global chemical transport models to identify pollution source regions (Chen et al., 2009; Park et al., 2009; Lamarque and Hess, 2003). The WRF-STEM model domain was centered on $50.377^{\circ} \mathrm{E}$ longitude and $29.917^{\circ} \mathrm{N}$ latitude, with a model horizontal grid resolution of $45 \times 45 \mathrm{~km}$ with 200 grids in the east-west direction and 125 north-south. The meteorological variables needed for the chemical transport were derived from the WRF meteorological model (Grell et al., 2005) using FNL (Final) data (ds083.2) available from the University Corporation for Atmospheric Research (UCAR) website as input data. The main aim of the simulation was to identify the geographic locations contributing to the observed pollutants at the field sites. The HTAP version 2 emission inventory, which comprises multiple pollutants including BC and OC, was used for the WRF-STEM modeling (available from http://edgar.jrc.ec.europa.eu/htap_v2/, last access: January 2017). This emission inventory includes major sectors, such as energy, industry, transport, and residential, but not large-scale open agricultural and open forest burning. The simulations applied in our study used the anthropogenic emissions from the HTAP inventory. Thus, the results indicate the amount of pollutants reaching the study area from day-to-day planned and recurring activities in domestic, transport, industrial, and other sectors. The model was run for a month prior to the field campaign dates to allow for model spin-up (normal practice for a regional chem- 
ical transport model) and then for the months of December, January, and June to match the field campaign dates.

\section{Results and discussion}

\section{1 $\mathrm{BC}, \mathrm{OC}$, and dust concentrations}

The minimum, maximum, and average concentrations of $\mathrm{BC}, \mathrm{OC}$, and dust in the ice and snow samples are given in Table 1. The $\mathrm{OC}$ and $\mathrm{BC}$ concentration values were blank corrected by subtracting the average value of the field blanks. Blank concentrations were used to calculate detection limits as mean \pm standard deviation. The average $\mathrm{BC}$ concentration overall was $2130 \pm 1560 \mathrm{ng} \mathrm{g}^{-1}$ in summer samples, $2883 \pm 3439 \mathrm{ng} \mathrm{g}^{-1}$ in autumn samples (both from glaciers), and $992 \pm 883 \mathrm{ng} \mathrm{g}^{-1}$ in winter samples. The average OC concentration overall was $1839 \pm 1108 \mathrm{ng} \mathrm{g}^{-1}$ in summer samples, $1423 \pm 208 \mathrm{ng} \mathrm{g}^{-1}$ in autumn samples, and $1342 \pm 672 \mathrm{ng} \mathrm{g}^{-1}$ in winter samples. There was considerable variation in individual samples, with summer values of $\mathrm{BC}$ ranging from $82 \mathrm{ng} \mathrm{g}^{-1}$ (Gulkin glacier) to $10502 \mathrm{ng} \mathrm{g}^{-1}$ (Henarche glacier), autumn values from $125 \mathrm{ng} \mathrm{g}^{-1}$ (Gulkin glacier) to $6481 \mathrm{ng} \mathrm{g}^{-1}$ (Sachin glacier), and winter samples from $79 \mathrm{ng} \mathrm{g}^{-1}$ (Kalam) to $5957 \mathrm{ng} \mathrm{g}^{-1}$ (Sost).

The lowest BC $\left(82 \mathrm{ng} \mathrm{g}^{-1}\right)$ and OC $\left(128 \mathrm{ng} \mathrm{g}^{-1}\right)$ concentrations were observed in summer samples collected from the Gulkin and Sachin glaciers, respectively. The average values of BC and OC were low in all samples from the Passu glacier, even though it lies close to the Karakoram highway which links Pakistan with China. The low concentrations of $\mathrm{BC}$ may have been due to the east-facing aspect of the glacier shielding it from pollutants transported from west to east. Slope aspect of a glacier is known to be important for snow cover dynamics (Gul et al., 2017); dust concentrations are known to vary with slope aspect due to the effects of wind direction on deposition.

The highest average concentration of $\mathrm{BC}$ was found in autumn samples from the Sachin glacier and the highest average concentration of $\mathrm{OC}$ in summer samples from the same glacier. The average concentration of $\mathrm{BC}$ was much greater in autumn than in summer on the Sachin glacier but somewhat greater in summer than in autumn on the Gulkin glacier, indicating highly spatiotemporal patterns in the deposition of particles. The marked difference on the Sachin glacier may have reflected the difference in the direction of air, which comes from Iran and Afghanistan in summer and the Bay of Bengal via India in autumn, with the generally lower deposition on the Gulkin glacier more affected by other factors (such as slope aspect of the glacier and status of local emissions near the glacier). There was no clear correlation between the average $\mathrm{BC}$ concentration in glacier samples and glacier elevation. However, winter snow samples showed a weak increasing trend in average $\mathrm{BC}$ with site elevation (Table 1, Fig. S3).
Most summer samples were collected from surface ice (Fig. S2a), but a few samples for Gulkin and Sachin were collected from aged snow on the glacier surface (Fig. S2b, c). Dust was visible on the relatively aged snow, and the $\mathrm{BC}$ and OC concentrations in these snow samples were much higher than those in ice. The highest average $\mathrm{BC}$ values in winter were also observed in aged snow (from Sost) and the lowest in fresh snow (from Kalam) (Table 1). Generally, snow samples collected within $24 \mathrm{~h}$ of a snowfall event were considered to be fresh snow.

We analyzed the ratios of OC to BC in the different samples as in atmospheric fractions; this can be used as an indicator of the emission source, although apportionment is not simple and only indicative. The BC fraction is emitted during the combustion of fossil fuels, especially biomass burning in rural areas in winter, and urban emissions from road transport. The OC fraction can be directly emitted to the atmosphere as particulate matter (primary OC) from fossil fuel emissions, from biomass burning, or in the form of biological particles or plant debris; it can also be generated in the atmosphere as gases are converted to particles (secondary OC). In general, lower OC / BC ratios are associated with fossil fuel emissions and higher $\mathrm{OC} / \mathrm{BC}$ ratios with biomass burning. Overall, there was no clear correlation between $\mathrm{BC}$ and $\mathrm{OC}$ concentrations in our samples. In most cases, the concentration of $\mathrm{OC}$ was greater than the concentration of $\mathrm{BC}$, which might indicate a greater contribution from biomass burning in the emissions, but in a few, the concentration of $\mathrm{BC}$ was greater than that of $\mathrm{OC}$, which might indicate a greater contribution from coal combustion. The lowest OC / BC ratio of 0.041 was observed in a summer sample from Henarche glacier and the highest ratio of 5 in a winter sample from Kalam. The higher value at Kalam may indicate greater contributions from biomass burning than from fossil fuel combustion in the region. In summer samples, the average concentration of OC was greater than the average concentration of BC in samples from four of the six glaciers, but it was much lower in Barpu and Henarche. In winter, individual snow samples indicated that the concentration of $\mathrm{OC}$ was greater than $\mathrm{BC}$ at low-elevation sites and vice versa; the average $\mathrm{OC}$ was greater than average $\mathrm{BC}$ at all except the highest elevation site (Table 1).

However, these results should be considered with caution. There are a number of factors that can affect the OC / BC ratio in snow and ice samples apart from the concentrations in the atmosphere. Spatiotemporal variability of the OC / BC ratio may indicate the contribution of different sources, seasonal variation, and frequent change in wind direction. In deposited samples, low $\mathrm{OC} / \mathrm{BC}$ ratios can result from a reduction in OC (Niu et al., 2017), greater contributions from $\mathrm{BC}$ enrichment and OC scavenging, and/or the contribution of different emission sectors (including quantity, combustion conditions, and fuel type). Post-deposition processes of scavenging and enrichment, which are influenced by the snowmelt rate, can cause water-soluble OC to be underrep- 
Table 1. Concentration of black carbon, organic carbon, and dust in summer, autumn, and winter samples in 2015 and 2016.

\begin{tabular}{|c|c|c|c|c|c|c|c|c|}
\hline $\begin{array}{l}\text { Glacier/ } \\
\text { site }\end{array}$ & No. & $\begin{array}{r}\text { Elevation (m a.s.l.) } \\
\text { min-max }\end{array}$ & $\begin{array}{r}\text { BC min-max (avg) } \\
\left(\mathrm{ng} \mathrm{g}^{-1}\right)\end{array}$ & $\begin{array}{r}\text { OC min-max (avg) } \\
\left(\mathrm{ng} \mathrm{g}^{-1}\right)\end{array}$ & $\begin{array}{r}\text { Dust min-max (avg) } \\
\left(\mu \mathrm{g} \mathrm{g}^{-1}\right)\end{array}$ & $\begin{array}{l}\text { Type }{ }^{\mathrm{a}} \\
\text { snow age in days }\end{array}$ & $\mathrm{OC} / \mathrm{BC}^{\mathrm{b}}$ & Year \\
\hline \multicolumn{9}{|c|}{ Summer (May 2015/May 2016) } \\
\hline Barpu & 6 & 2901-3405 & $877-5994$ (2938) & $244-1228$ (691) & $292-5250(1998)$ & DCI & $0.07-1.38$ & 2015 \\
\hline Gulkin & 31 & 2741-3319 & $82-5676(1327)$ & $238-8514(1594)$ & $31-2039(648)$ & DCIS & $0.169-3.76$ & $2015 / 16$ \\
\hline Henarche & 4 & $2569-2989$ & $778-10502(4820)$ & $275-4176(1628)$ & $225-2723(993)$ & Ice & $0.04-1.63$ & 2015 \\
\hline Mear & 8 & 2961-3539 & $222-3656(1593)$ & $703-6588$ (2992) & $33-656(211)$ & DCI & $0.72-4.88$ & 2015 \\
\hline Passu & 14 & $2663-3158$ & $87-734(346)$ & $132-1810(741)$ & 28-524 (196) & DCI & $1.85-4.80$ & 2015 \\
\hline Sachin & 35 & $3414-3895$ & $257-4127$ (1769) & $128-7592(3348)$ & $5.6-2495(314)$ & DCIS & $0.08-0.53$ & $2015 / 2016$ \\
\hline Total & 98 & & & & & & & \\
\hline \multicolumn{9}{|c|}{ Autumn (Oct 2016) } \\
\hline Gulkin & 7 & 2741-3319 & $125-1028(451)$ & 266-3574 (1276) & $60-767(253)$ & DCIS & $1.29-3.59$ & 2016 \\
\hline Sachin & 6 & $3414-3895$ & $4342-6481(5314)$ & 543-3478 (1571) & $124-1348(546)$ & DCIS & $0.11-0.53$ & 2016 \\
\hline Total & 13 & & & & & & & \\
\hline \multicolumn{9}{|c|}{ Winter (Dec 2015/Jan 2016) } \\
\hline S1-Sost & 6 & 2873-3092 & $482-5957$ (2506) & 378-2934 (1039) & 29-311 (131) & $2-17 \mathrm{~d}$ & $0.25-0.78$ & 2015 \\
\hline S2-Hopar & 2 & $2602-2794$ & $229-1064(646)$ & $330-1976(1153)$ & $23-129(76)$ & $1-15 \mathrm{~d}$ & $1.4-1.8$ & 2016 \\
\hline S3-Tawas & 1 & 2437 & 650 & 1320 & 16 & $8-17 \mathrm{~d}$ & 2.03 & 2016 \\
\hline S4-Astore & 3 & $2132-2396$ & $450-2640(1305)$ & 914-3645 (2161) & 55-171 (97) & $4-7 \mathrm{~d}$ & $1.38-2.33$ & 2016 \\
\hline S5-Shangla & 2 & $2324-2373$ & $367-1110(739)$ & 1302-2856 (2079) & $13-49(31)$ & $8-9 \mathrm{~d}$ & $2.5-3.5$ & 2016 \\
\hline S6-Kalam & 4 & 1933-2101 & 79-123 (107) & 214-558 (347) & 4-6 (5) & $1 \mathrm{~d}$ & $2.3-5$ & 2016 \\
\hline Total & 18 & & & & & & & \\
\hline
\end{tabular}

a Type: snow or ice type; DCI: debris-covered ice; DCIS: debris-covered ice and aged snow. ${ }^{\mathrm{b}}$ range of OC / BC in individual samples.

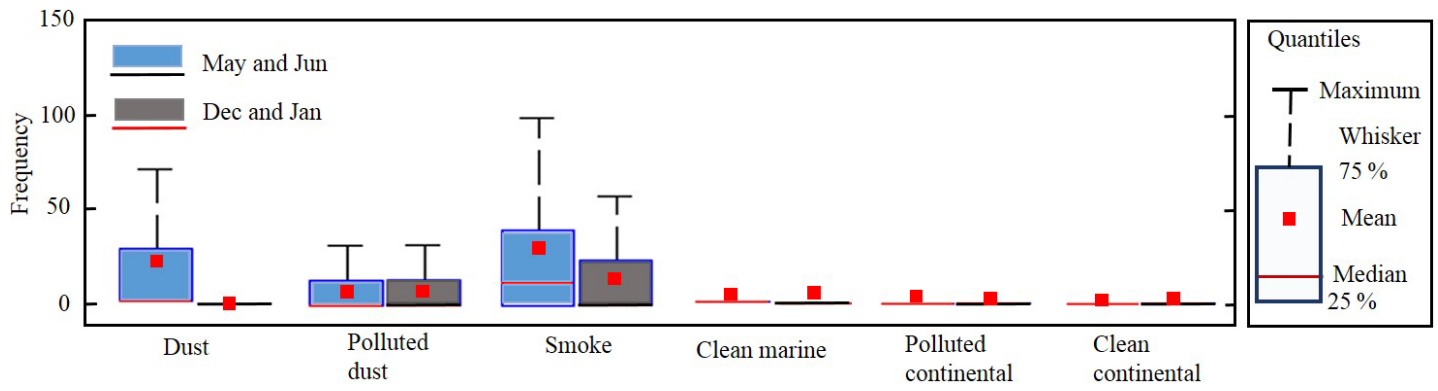

Figure 2. Frequency distribution of aerosol subtypes in the atmosphere over the study region calculated from CALIPSO data; average for the study months in 2006 to 2014.

resented as meltwater removes $\mathrm{OC}$ but not $\mathrm{BC}$, with $\mathrm{OC}$ and $\mathrm{BC}$ being redistributed primarily by meltwater rather than by sublimation and/or dry/wet deposition. Thus, the OC / BC ratio often reflects the impact of the dilution of dissolved organic carbon and the enrichment of primary organic carbon during snow/ice melting, with differences in OC / BC ratios reflecting differences in the enrichment process. The low $\mathrm{OC} / \mathrm{BC}$ ratio in the samples from Henarche, the glacier at the lowest elevation, could, for example, be due to preferential washing out of OC particles with meltwater. Overall, there was a higher positive correlation between $\mathrm{BC}$ and dust than with $\mathrm{OC}$, suggesting that for $\mathrm{BC}$ and dust, particle precipitation and enrichment processes were similar. The method used for analysis and the amount of dust loading on the sample can also affect the $\mathrm{OC} / \mathrm{BC}$ ratio, as can the pres- ence of metal oxides and calcium carbonate. High iron oxide concentrations can cause $\mathrm{BC}$ to pre-oxidize or drop off the filter, while calcium carbonate can be wrongly identified as BC. Laboratory studies have shown that the presence of metal oxides in aerosol samples can alter the OC / BC ratio either by enhancing $\mathrm{OC}$ charring or by lowering the $\mathrm{BC}$ oxidation temperature (Wang et al., 2010), while higher fractions of metal oxide can increase $\mathrm{BC}$ divergence across the thermal optical protocols (Wu et al., 2016). Dust can lead to a greater decrease in optical reflectance during the $250{ }^{\circ} \mathrm{C}$ heating stage in the thermal-optical method and thus an incorrect OC / BC ratio (M. Wang et al., 2012). Carbon detected by the flame ionization detector (FID) before the optical signal attains the initial value is defined as OC and that detected after is defined as $\mathrm{BC}$; dust on the filter results in the FID division 
being postponed or inefficient and thus OC being overestimated and $\mathrm{BC}$ underestimated or even negative (M. Wang et al., 2012). M. Wang et al. (2012) provide a more detailed discussion of OC / BC ratios derived using the thermal optical method.

A wide range of values has been reported by different authors for $\mathrm{BC}$ concentrations in snow and ice samples from different regions (Table S2). The concentrations of BC in our samples were higher than those reported by many authors (Table S2) but were comparable with the results reported by $\mathrm{Xu}$ et al. (2012) in the Tien Shan, by Li et al. (2016) in the northeast of the Tibetan Plateau, by Wang et al. (2017) in northern China, and by Zhang et al. (2017) in western Tien Shan, central Asia. High concentrations indicate high deposition rates on the snow and ice surface, but there are several possible reasons for a wide variation in values apart from differences in deposition rates, including differences in sampling protocols, geographical/sampling location and elevation of sampling site (Qu et al., 2014), and year/season of sampling. The majority of samples were from the ablation zone of the glaciers. Strong melting of surface snow and ice in the ablation zone could lead to $\mathrm{BC}$ enrichment and high-BC concentrations, as observed by Li et al. (2017) for glaciers on the southern Tibetan Plateau. The sampling season (May to September in our study) is an important factor because rapid enrichment occurs as snowmelts during the melting season. The peak melting period is May to August/September; thus, the concentration of $\mathrm{BC}, \mathrm{OC}$, and dust in our samples would have been increased as melting progressed due to the enrichment in melting snow and scavenging by the melting water. In most cases, snow and ice samples were collected quite a long time after snow fall, and the concentration of pollutants would also have increased in the surface snow and ice due to dry deposition. It seems likely that the pollutants in surface samples would be affected by sublimation and deposition until the next melt season (Yang et al., 2015). In some of the cases in our study, the average concentration of BC, OC, and/or dust for a particular glacier/site was increased as a result of a single highly concentrated sample, reflecting the wide variation that results from the interplay of many factors.

Enrichment is more marked at lower elevations as the temperatures are higher, which enhances melting and ageing of surface snow, while deposition also tends to be higher because the pollutant concentrations in the air are higher (J. Wang et al., 2012; Nair et al., 2013). Previous studies have tended to focus on the accumulation area of glaciers (e.g., ice cores and snow pits), where enrichment influences are less marked, and on high-elevation areas, where deposition is expected to be lower, in both cases leading to lower values. In our study, the majority of samples collected in summer and autumn were collected from the ablation area of debriscovered glaciers where enrichment influences are marked due to the relatively high temperature, and this is reflected in the relatively high values of $\mathrm{BC}, \mathrm{OC}$, and dust. $\mathrm{Li}$ et al. (2017) showed a strong negative relationship between the elevation of glacier sampling locations and the concentration of light-absorbing particles. Stronger melt at lower elevations leads to higher pollutant concentrations in the exposed snow. Equally, BC may be enriched in the lower-elevation areas of glaciers as a result of the proximity to source areas as well as by the higher temperatures causing greater melting. Thus, the main reason for the high concentrations of $\mathrm{BC}, \mathrm{OC}$, and dust in our samples may have been that the samples were taken from relatively low-elevation sites. Human activities near the sampling sites in association with the summer pilgrimage season probably also contributed to an increase in pollutant concentrations. Our results do not necessarily indicate that all the glaciers in the Karakoram region are substantially darkened by BC. The ablation zones of debris-covered glaciers which are at relatively low elevations and near pollution sources may be more polluted than other glacier areas.

\subsection{Frequency distribution of aerosol subtypes in the atmosphere}

The analysis of aerosol types using the CALIPSO data identified smoke as the most frequent aerosol type over the study region in both summer and winter, indicating that biomass burning may be the dominant source of emissions. Figure 2 shows the average frequency of different aerosol types in May-June (summer) and December-January (winter) over the period 2006 to 2014 in the form of a box plot. The frequency of different aerosol subtypes in June from 2006 to 2014 is shown in Fig. S4; smoke had the highest frequency (39\%), followed by dust ( $21 \%)$, polluted dust $(12 \%)$, and other (20\%). This type of aerosol measurement in the atmosphere was useful for our current study because it provides observation-based data over the study region, whereas the other approaches used (such as modeling) were based on interpolation not observation. Pollutant deposition depends on the concentration of pollutants in the atmosphere, and the results are consistent with the high concentration of BC (from smoke) and dust particles in the glacier and snow surface samples.

\subsection{Snow albedo reduction}

The albedo of individual winter snow samples was calculated using the SNICAR model and then averaged for each site (S1 to S6). Figure 3a shows the average for each site across the visible and infrared spectrum. Two sites were chosen for further analysis: S1 (Sost), which had the highest average concentration of BC, and S6 (Kalam), which had the lowest average concentration of BC. The albedo was simulated for selected MAC values and SZA for samples at the two sites, as described in Sect. 2.4 ("Methods"). The values for the average albedo of samples from the two sites simulated for MAC values of 7.5, 11, and $15 \mathrm{~m}^{2} \mathrm{~g}^{-1}$ and SZA of $57.0-88.9^{\circ}$ (daytime) under a clear sky ranged from 0.39 

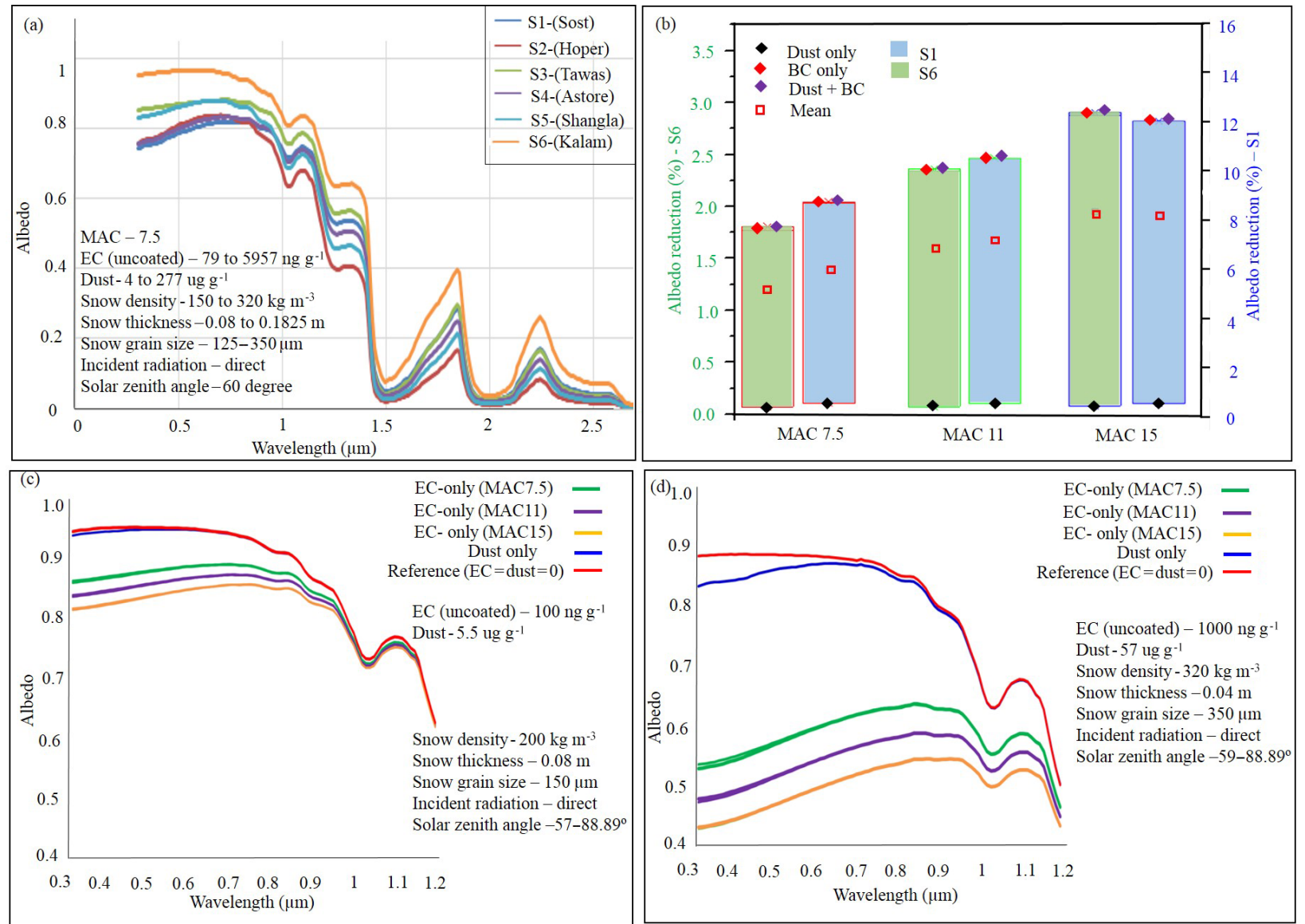

Figure 3. Spectral variation in albedo for winter sampling sites and selected mass absorption cross-section (MAC) values: (a) average albedo of samples at each of the sites; (b) daily mean albedo reduction of fresh snow (site S6) and aged snow (site S1) snow (note different scales of $y$ axis); (c) albedo of fresh snow site S6; (d) albedo of aged snow site S1.

(site S1, BC only, midday, MAC $15 \mathrm{~m}^{2} \mathrm{~g}^{-1}$ ) to 0.85 (site S6, dust only, early evening, MAC $7.5-15 \mathrm{~m}^{2} \mathrm{~g}^{-1}$ ). The detailed values are shown in Table S3.

The percentage change in albedo was calculated in absolute terms as the change between albedo values with a pollutant (BC or dust or both) and a reference albedo value with zero pollutants (zero BC and dust concentration). Table 2 shows the calculated percentage reductions in daily minimum, maximum, and mean broadband snow albedo at different MAC values $\left(7.5,11,15 \mathrm{~m}^{2} \mathrm{~g}^{-1}\right)$ resulting from the average $\mathrm{BC}$, dust, and combined $\mathrm{BC}$ and dust concentrations found in samples at each of the sites. The reduction was strongly dependent on BC concentration and almost independent of dust concentration and increased with increasing MAC value. The results suggest that $\mathrm{BC}$ was the dominant forcing factor, rather than dust, influencing glacial surface albedo and accelerating glacier melt. $\mathrm{BC}$ was found to play an important role in forcing in the northern Tibetan Plateau (Li et al., 2016), whereas in the central Tibetan Plateau and the Himalayas, dust played a more important role $(\mathrm{Qu}$ et al., 2014; Kaspari et al., 2014). The MAC value affected the albedo more in the visible range than at $1.2 \mu \mathrm{m}$ (nearinfrared) wavelength (Fig. 3c, d). The combined concentration of $\mathrm{BC}$ and dust, or $\mathrm{BC}$ alone, strongly reduced the snow albedo for a given combination of other input parameters. The effect at the low-pollutant site (S6) was small: the values for daytime snow albedo at $0.975 \mu \mathrm{m}$ due to $\mathrm{BC}$, or BC plus dust with different MAC and SZA, ranged from 0.70 to 0.83 , with a reduction in daily mean albedo of 1.8 to $2.9 \%$, and those for dust alone range from 0.79 to 0.85 , with a reduction in daily mean albedo of less than $0.1 \%$. The effect at the high-pollutant site (S1) was much more marked: $\mathrm{BC}$ or $\mathrm{BC}$ and dust reduced daytime snow albedo to values ranging from 0.39 to 0.64 , a reduction in daily mean albedo of 8.8 to $12.0 \%$, but the effect of dust alone was still low, with values of 0.70 to 0.78 , again representing a reduction in daily mean albedo of less than $0.1 \%$.

Both the snow albedo and the impact of light-absorbing particles depend on a range of factors including the SZA, snow depth, snow grain size, and snow density. For example, the snow albedo reduction due to $\mathrm{BC}$ is known to be less in the presence of other light-absorbing particles as these 
will absorb some of the available solar radiation (Kaspari et al., 2011). The snow albedo calculated for our samples was strongly dependent on the SZA with albedo increasing with decreasing SZA, especially at near-infrared wavelengths (Table S3).

The impact of snow ageing was also investigated. The winter samples from S1 (Sost) were aged snow, whereas those from S6 (Kalam) were fresh snow (Table 1, Fig. S5b, c). Not only was dust clearly visible on the surface of the aged snow, the grain size was large and the snow was dense. The aged snow had a much higher concentration of BC and dust, which reduced the albedo, but the extent of reduction is also affected by other factors. Albedo reduction by BC and dust particles is known to be greater for aged snow than for fresh snow (Warren and Wiscombe, 1985). In our samples, the calculated reduction in snow albedo for high MAC values (15) compared to low MAC values (7.5) was greater in aged snow than in fresh snow (Fig. 3b). The effective grain size of snow increases with time as water surrounds the grains. Snow with a larger grain size absorbs more radiation because the light can penetrate deeper into the snowpack, thus decreasing surface albedo (Flanner and Charles, 2006). In the melting season, the snowpack becomes optically thin and more particles are concentrated near the surface layer, which further increases the effect on albedo.

The estimated reduction in snow albedo by dust and BC (up to $29 \%$ of the daytime maximum value, Table 2) was higher than that reported by others for high Asia based on farmers' recordings (e.g., 1.5 to $4.6 \%$ reported by Nair et al., 2013) and in the Himalayas (Ming et al., 2008; Kaspari et al., 2014; Gertler et al., 2016). However, although the values were relatively high, they were at the same level or lower than the estimates for an albedo reduction of $28 \%$ by $\mathrm{BC}$ and $56 \%$ by dust in clean ice samples and of $36 \%$ by BC and $29 \%$ by dust in aged snow samples, reported by $\mathrm{Qu}$ et al. (2014) for surface samples from the Zhadang glacier, China. Simulation results by Ming et al. (2013) showed BC, dust, and grain growth to reduce the broadband albedo by 11 , 28 , and $61 \%$, respectively, in a snowpack in central Tibet. Dust was the most significant contributor to albedo reduction when mixed inside the snow and ice or when the glacier was covered in bare ice. In our case BC was a more influential factor than dust during a similar study period to that reported by Li et al. (2017), indicating that BC plays a major role in albedo reduction.

The possible reasons for the relatively high values for albedo reduction in our samples include the lower elevation of the sampling locations, relatively high concentrations of $\mathrm{BC}$ and dust, high MAC values, low snow thickness, underlying ground quality, the presence of small and large towns near the sampling sites, and the predominance of aged snow samples. Most of the samples collected in winter were from places with a snow depth of less than $50 \mathrm{~cm}$ (Fig. S5a); thus, mud, stones, and clay below the snow layer would be ex- pected to increase the absorption of solar radiation and reduce the albedo.

The high albedo reduction in the visible range of the electromagnetic spectrum could be due to the relatively high concentration of surface snow impurities. The total amount of deposited particles in the surface layer of aged snow was relatively high, indicating a high deposition rate of atmospheric pollutants.

Flanner et al. (2007) reported that BC emission and snow ageing are the two largest sources of uncertainty in albedo estimates. The uncertainties in our estimated albedo reduction include the BC type (uncoated or sulfate coated), the size distribution of dust concentration, the accuracy of snow grain size, snow texture, snow density, and the albedo of the underlying ground. Sulfate-coated particles have an absorbing sulfate shell surrounding the carbon; recent studies confirm that coated $\mathrm{BC}$ has a larger absorbing power than non-coated BC (Naoe et al., 2009). We used uncoated black carbon concentration in the SNICAR model, but the pollutants at the remote site are presumed to be mainly from long-range transport; thus, the BC may have gained some coating. The albedo reduction for sulfate-coated black carbon was calculated to be $3-8.5 \%$ higher, depending on the MAC and SZA values, than for uncoated black carbon at the low-concentration site S6 (Fig. S6). The snow grain size (snow aging) and snow texture are also large sources of uncertainty. The effect of snow grain size is generally larger than the uncertainty in lightabsorbing particles and varies with the snow type (Schmale et al., 2017). The albedo reduction caused by $100 \mathrm{ng} \mathrm{g}^{-1}$ of $\mathrm{BC}$ for an effective snow grain radius of 80,100 , or $120 \mu \mathrm{m}$ was calculated to be $0.017,0.019$, or 0.021 , respectively. The snow grain size was measured with a hand lens with an accuracy of $20 \mu \mathrm{m}$; thus, the associated uncertainty in the albedo results was at least 0.002 . The snow grain shape was measured with the help of a snow card, but a spherical shape was assumed for snow grains in the (online) SNICAR albedo simulation model. The albedo of nonspherical grains is higher than the albedo of spherical grains (Chen et al., 2016), and the shape of snow grains and/or ice crystals changes significantly with snow age and meteorological conditions during and after snowfall (LaChapelle, 1969). A number of recent studies (e.g., Flanner et al., 2012; Liou et al., 2014; He et al., 2014, 2017) have shown that both snow grain shape and aerosol-snow internal mixing play an important role in snow albedo calculations.

\subsection{Radiative forcing}

RF is a measure of the capacity of a forcing agent to affect the energy balance in the atmosphere - the difference between sunlight absorbed by the Earth and energy radiated back to space - thereby contributing to climate change. Changes in albedo contribute directly to radiative forcing: a decrease in albedo means that more radiation will be absorbed and the temperature will rise. In snow and ice, the additional energy 
Table 2. Snow albedo reduction (\%) by black carbon, dust, and black carbon plus dust at the site with the lowest average pollutant concentration (S6) and the site with the highest average pollutant concentration (S1) under different mass absorption cross-section (MAC) values.

\begin{tabular}{lr|rrr|rrr}
\hline Pollutant & MAC value & \multicolumn{3}{c|}{ Low-concentration site (S6) } & \multicolumn{2}{c}{ High-concentration site (S1) } \\
\hline & $\left(\mathrm{m}^{2} \mathrm{~g}^{-1}\right)$ & Daytime min & Daytime max & Daily mean & Daytime min & Daytime max & Daily mean \\
\hline Black carbon & 7.5 & 2.8 & 5.1 & 1.8 & 15.6 & 23.9 & 9.0 \\
& 11 & 3.7 & 6.9 & 2.3 & 19.2 & 28.6 & 10.5 \\
& 15 & 4.6 & 8.3 & 2.9 & 22.3 & 32.5 & 12.0 \\
\hline Dust & 7.5 & 0.1 & 0.2 & 0.07 & 0.9 & 1.6 & 0.05 \\
& 11 & 0.1 & 0.2 & 0.07 & 0.9 & 1.6 & 0.05 \\
& 15 & 0.1 & 0.2 & 0.07 & 0.9 & 1.6 & 0.05 \\
\hline Black carbon and dust & 7.5 & 2.9 & 5.2 & 1.8 & 15.7 & 24.0 & 8.8 \\
& 11 & 3.8 & 6.8 & 2.4 & 19.2 & 28.6 & 10.5 \\
& 15 & 4.6 & 8.3 & 2.9 & 22.3 & 32.5 & 12.0 \\
\hline
\end{tabular}

absorbed by any pollutants present also increases and accelerates the melting rate.

Various authors have described the impact of albedo change in snow and ice on radiative forcing. Zhang et al. (2017) reported that a reduction in albedo by 9 to $64 \%$ can increase the instantaneous radiative forcing by as much as $24.05-323.18 \mathrm{~W} \mathrm{~m}^{-2}$. Nair et al. (2013) estimated that in aged snow a BC concentration of $10-200 \mathrm{ng} \mathrm{g}^{-1}$ can increase radiative forcing by 2.6 to $28.1 \mathrm{~W} \mathrm{~m}^{-2}$, while Yang et al. (2015) reported radiative forcing of $18-21 \mathrm{~W} \mathrm{~m}^{-2}$ for aged snow in samples from the westernmost Tibetan Plateau. The authors used different atmospheric conditions in the forcing estimates: Zhang et al. (2017) used midlatitude winter with a clear sky and a cloudy environment, Nair et al. (2013) midlatitude winter, and Yang et al. (2015) clearsky and cloudy conditions.

We calculated the radiative forcing in the samples assessed for daytime albedo and daily $(24 \mathrm{~h})$ mean albedo. The radiative forcing at different daylight times caused by $\mathrm{BC}$ deposition varied from 3.93 to $43.44 \mathrm{~W} \mathrm{~m}^{-2}\left(3.93-11.54 \mathrm{~W} \mathrm{~m}^{-2}\right.$ at the low-BC site and $20.88-43.45 \mathrm{~W} \mathrm{~m}^{-2}$ at the high-BC site) and that cause by dust from 0.16 to $2.08 \mathrm{~W} \mathrm{~m}^{-2}(0.16$ $0.30 \mathrm{~W} \mathrm{~m}^{-2}$ at the low-BC site and $1.38-2.08 \mathrm{~W} \mathrm{~m}^{-2}$ at the high-BC site) (detailed values given in Table S4), indicating that $\mathrm{BC}$ was the dominant factor. The radiative forcing due to combined $\mathrm{BC}$ and dust was very similar to that for $\mathrm{BC}$ alone. In contrast, studies by others have shown higher forcing by dust than by $\mathrm{BC}$ based on the optical properties and size distribution of dust particles (Qu et al., 2014). In our study, the increase in daily mean radiative forcing ranged from $0.1 \%$ for dust only at the low-pollutant site to $14.9 \%$ for BC at the high-pollutant site. However, dust forcing varies strongly with dust optical properties, source material, and particle size distribution. The properties for dust are unique in each of the four size bins used in the SNICAR online model. These size bins represent partitions of a lognormal size distribution. We used an estimated size of dust particles and generic dust

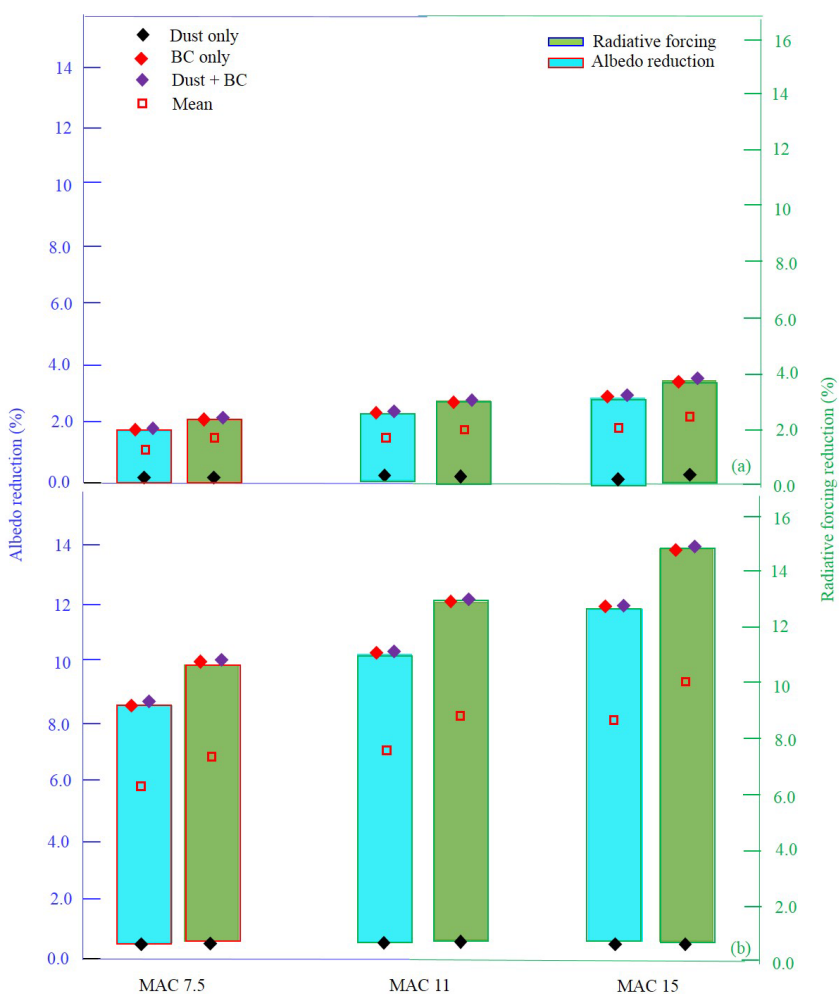

Figure 4. Daily mean radiative forcing reduction and albedo reduction (\%) caused by black carbon and dust for different mass absorption cross-section values (MAC) in (a) fresh (low black carbon) and (b) aged (high black carbon) snow samples (note different scales of $y$ axis).

properties in the model, but some dust particles can have a larger impact on snow albedo than the dust applied here (e.g., Painter et al., 2007).

Both radiative forcing and albedo reduction increased with decreasing daytime SZA, indicating higher melting at midday compared to morning and evening. Figure 4 shows the 
daily mean albedo reduction and corresponding radiative forcing caused by $\mathrm{BC}$ for fresh (low-BC) and aged (high-BC) snow with different MAC values. Snow aging (snow grain size) plays an important role in albedo reduction and radiative forcing. According to Schmale et al. (2017) the effect of snow grain size is generally larger than the uncertainty in light-absorbing particles, which varies with snow type. Snow aging reduces snow albedo and accelerates snowmelt, but the impact of snow aging on $\mathrm{BC}$ in snow and the induced forcing is complex and includes spatial and seasonal variation (Qian et al., 2014).

An increase in MAC value from 7.5 to 15 led to an increase in radiative forcing by $1.48 \mathrm{~W} \mathrm{~m}^{-2}$ in fresh snow and $4.04 \mathrm{~W} \mathrm{~m}^{-2}$ in aged snow. This suggests that when the surface of snow, ice, and glaciers experiences strong melting, enrichment with $\mathrm{BC}$ and dust could cause more forcing. Previous studies of ice cores and snow pits probably underestimated the albedo reduction and radiative forcing in glacier regions as samples were taken from high-elevation areas where there is less ageing and melting and thus lower surface enrichment of BC and dust than at lower elevation. Our results are higher than those reported in other studies on the northern slope of the Himalayas (Ming et al., 2012), on the western Tibetan Plateau (Yang et al., 2015), and the Tien Shan (Ming et al., 2016). However, they are comparable to values for radiative forcing reported more recently by others, for example for the Muji glacier (Yang et al., 2015), Zhadang glacier (Qu et al., 2014), in high Asia (Flanner et al., 2007; Nair et al., 2013), and in the Arctic (Wang et al., 2011; Flanner, 2013). The results suggest that the enrichment of black carbon (in our case) and mineral dust (other authors) can lead to the increased absorption of solar radiation, exerting a stronger effect on climate and accelerating glacier melt.

\subsection{Potential source regions}

\subsubsection{Wind vector maps}

Figure 5 shows the spatial variance of wind vector maps $(U$ and $V)$ at $850 \mathrm{hPa}$ in May, June, January, and December prepared using MERRA-2 reanalysis data for the year 2015-2016. The wind blows primarily from west to east, but there were variations over the year. Central Asia contributed some part of the air in May and June. In May, the prevailing air masses were from Syria, Turkey, Turkmenistan, Iraq, Azerbaijan, northwest Iran, Afghanistan, Nepal, southwest China, and southern Pakistan; the trend was similar in June but with a smaller contribution from Nepal and southwest China. In December and January (winter), the western trade winds were stronger than the easterlies and the wind blew from Azerbaijan and northwest Iran, reaching the study site via Syria, Iraq, Turkmenistan, and Afghanistan.

\subsubsection{Coupled emissions inventory with back air trajectory}

Trajectory analysis using the HYSPLIT model showed that in May and June 2015, air parcels reached the study site along three different pathways: one from north Asia (Russia) via central Asia (Kazakhstan); one from western Asia (Cyprus and Syria) via central and southern Asia (Georgia),; and one via India, which was more local (Fig. 6). The trajectories in summer had distinct pathways, while those in winter were dispersed in all directions, partially covering west, east, and south Asia and completely covering central Asia. Figure 6 shows the product of extinction and emission calculated along the pathways of trajectories calculated using the vertical profile for aerosol extinction over the study region obtained from the monthly CALIPSO satellite-based extinction data. Scattering and absorption decreased exponentially with increasing elevation (Fig. S1) but were still visible at elevations above $5 \mathrm{~km}$ in summer.

The RCP emission data combined with back trajectories and extinction data showed that the hot spot regions of pollution that affected the study sites during winter were mainly to the southwest rather than very distant (Fig. 6b). Iran, Turkmenistan, Azerbaijan, Georgia, the eastern part of Turkey, and the southwestern part of Russia all showed comparatively high-pollutant emissions in winter which moved towards northern Pakistan. The western part of Kazakhstan, Uzbekistan, and northeastern Turkey emitted particularly high concentrations of pollutants.

The combination of the back-trajectory results and surface-wind direction analysis indicated that during the sampling months, aerosols were significantly influenced by the long-range transport of pollutants coming from central and south Asia, with a small contribution from west and east Asia. This differs somewhat from previous reports which suggested that the Tibetan Plateau and Himalayan region are mainly affected by pollutants from east and south Asia (Zhang et al., 2015). An increasing trend has been reported for black carbon emissions in central and south Asia over the past 150 years (Bond et al., 2007), and a significant increase has been found in black carbon concentrations in glacier snow in west China in the last 20 years, especially during the summer and monsoon seasons (Ming et al., 2008). In south Asia, the largest source of atmospheric black carbon is emission from biomass and biofuels used for cooking and heating (dung, crop residues, wood) (Venkataraman et al., 2005).

The results indicate that only a low level of pollutants (minor contribution) reached the study area from northwest China. BC particles emitted from distant low-latitude source regions such as tropical Africa barely reach the Tibetan Plateau and Himalayan regions because their emissions are removed along the transport pathways during the summer monsoon season (Zhang et al., 2015). 

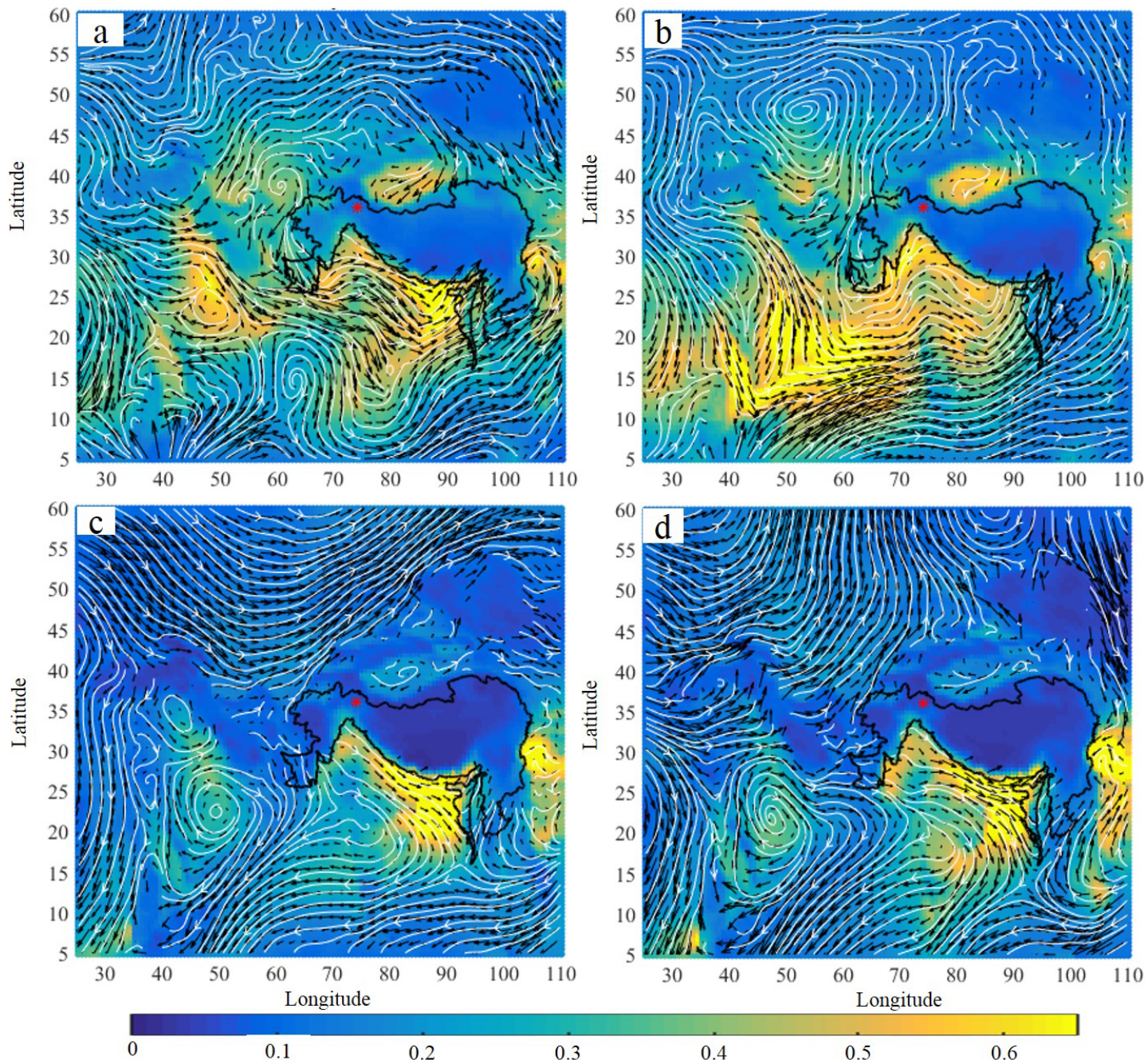

Figure 5. Monthly average horizontal wind patterns at $850 \mathrm{hPa}$ during (a) May, (b) June, (c) December, and (d) January, corresponding to approximately $2500 \mathrm{~m}$ a.s.l., from NASA Goddard Earth Sciences (GES) Data and Information Services Center (DISC). Red star indicates the position of the study area, and white lines indicate streamlines. The background colors show monthly mean aerosol optical depth.

\subsubsection{Chemical transport modeling}

The contribution of pollutants from potential source regions was also investigated using the WRF-STEM model with tagged carbon monoxide tracers and source regions of east Asia, south Asia, central Asia, the Middle East, Europe, the Russian Federation, and west Asia. (The individual countries in the regions are listed in Table S5.)

Figure 7 shows the results of the model simulations for summer (1 June to 4 July 2015) and winter (15 December 2015 to 17 January 2016) at two glacier sites (Sachin and Shangla), where the model terrain elevation was close to the observation terrain elevation. The model simulations showed Pakistan to be the major contributor of pollutants in summer (77\% at Shangla and $43 \%$ at Sachin) followed by the south Asian countries. The south Asian countries were the major contributor in winter $(47 \%$ at Shangla and $71 \%$ at Sachin) followed by Pakistan, which is in line with the findings by Lu et al. (2012) that south Asia contributed $67 \%$ black carbon in the Himalayas. There were minor contributions of $2-7 \%$ of pollutants from Afghanistan, Iran, central Asia, and the Middle East and extremely small amounts from east Asia, Europe, Africa, west Asia, and China. The contribution from Iran, the Middle East, and Europe was greater in winter than in summer, while the contribution from central Asia and China was greater in summer than in winter. The proportion of daily contributions fluctuated considerably, with higher contributions from Iran, the Middle East, and Europe on individual days in winter, ranging, for example, from 2 to $30 \%$ for the Middle East.

The concentration of hydrophobic $\mathrm{BC}(\mathrm{BC} 1)$, hydrophilic $\mathrm{BC}(\mathrm{BC} 2)$, and total black carbon $(\mathrm{BC}=\mathrm{BC} 1+\mathrm{BC} 2)$ given by the model for the Sachin glacier grid point in the summer and winter seasons is shown in the Supplement (Fig. S7). In 


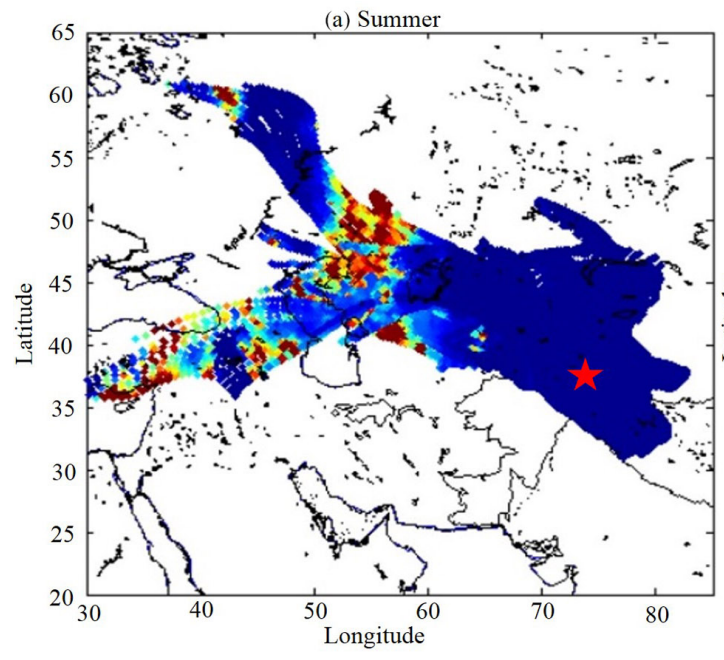

Possible polluted regions during summer: southwest Russia; western part of Kazakhstan, Iran and Turkmenistan; Uzbekistan; Georgia; northeast side of Turkey; Syria; Cyprus.

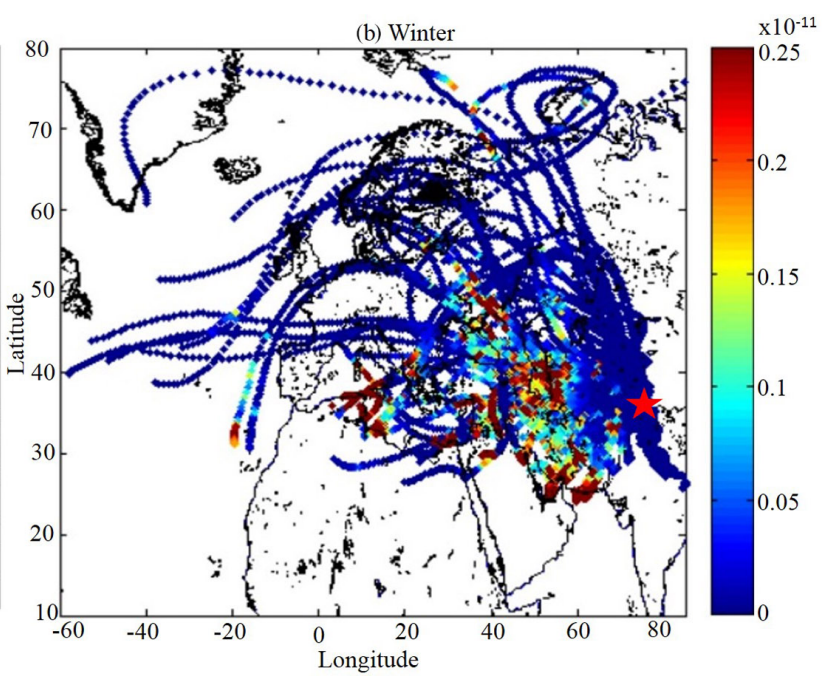

Possible polluted regions during winter: Iran; Pakistan; Iraq;

Turkmenistan; Azerbaijan; Georgia; Jordan; Syria; Tunisia; Ukraine;

Libya; Egypt; eastern part of Turkey and southwestern part of Russia.

Figure 6. Source contribution regions of pollutants identified using an emissions inventory (Representative Concentration Pathways) coupled with back trajectories: (a) 77 simulated days; (b) 63 simulated days. Red star indicates the position of the study area.

the model, freshly emitted BC particles are hydrophobic and gradually acquire a hygroscopic coating over time. A time series analysis of $\mathrm{BC} 1$ and $\mathrm{BC} 2$ concentrations shows the influence of both freshly emitted $\mathrm{BC}$ and aged $\mathrm{BC}$ reaching the observation location. The highest concentration of $\mathrm{BC} 1$ was observed on 20 December 2015 and the second highest on 25 June 2015, indicating an influence from freshly emitted air masses in both the summer and winter months. Future studies (BC tracer) will evaluate the details of the different source regions of the $\mathrm{BC}$ reaching the glaciers compared to region-tagged $\mathrm{CO}$ tracers.

\subsubsection{Comparison of the different approaches used to identify potential source regions}

The high-BC concentration in the atmosphere over the study region was attributed to long-range transport from urban source regions. Potential source regions of the pollutants deposited on glaciers and snow were identified using wind vector mapping with MERRA-2 reanalyzed data, calculation of back air trajectories using the HYSPLIT-4 model, and chemical transport pathways using the WRF-STEM tagged chemical transport model. The back-trajectory results indicated that the majority of pollutants in summer were from central and south Asia, and those in winter were from Iran, Pakistan, Iraq, Turkmenistan, Azerbaijan, Georgia, Jordan, Syria, Tunisia, Ukraine, Libya, and Egypt. The WRF-STEM model indicated that most anthropogenic pollutants were from Pakistan and south Asia during both summer and winter. However, both approaches showed a reasonable contribution from central Asian countries and a limited contribution from east Asian countries in summer. The wind vector maps also indicated that the study site was mostly affected by westerly winds. All three approaches showed a reasonable contribution from neighboring countries such as Afghanistan, Pakistan, Iran, and India in specific months. Overall, the results indicate that south, central, and west Asia were the major sources of the pollutants detected at the sampling sites.

There was some mismatching in source regions among the three approaches. The WRF-STEM model and wind vector maps both identified a small contribution from east Asia, but this was not identified in the back trajectories approach. Similarly, the wind vector maps and back air trajectories showed a dominant contribution from the west, while the WRFSTEM model showed a major contribution from Pakistan and south Asia. The differences in the results obtained by the different methods may be due in part to the complex topography of the region and the different altitudes used in the methods, the coarse resolution of the WRF-STEM model, and differences in the emission source inventories and meteorological parameters used by the WRF-STEM and HYSPLIT-4 models. The limitations of using back trajectories to identify source regions is discussed further in a paper by Jaffe et al. (1999).

Furthermore, the atmospheric BC concentration over the Himalayas has significant temporal variations associated with synoptic and mesoscale changes in the advection pattern (Babu et al., 2011) which can affect pollutant transport and deposition. The large uncertainty among different emission inventories can also affect the results, especially in the Himalayan region. 


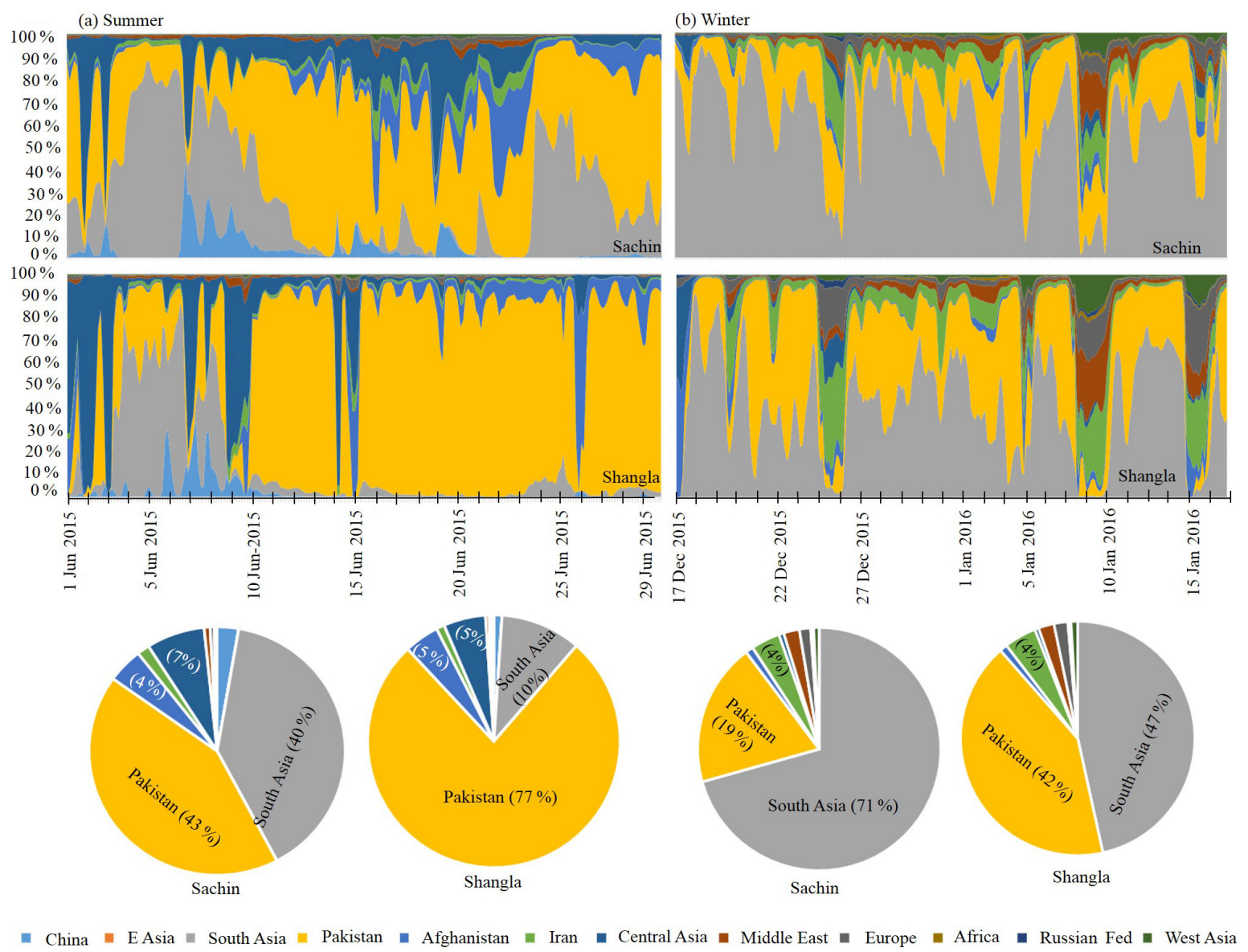

Figure 7. Source contribution regions of carbon monoxide for selected sites identified by WRF-STEM during (a) summer and (b) winter.

\section{Summary and conclusion}

$\mathrm{BC}$ and $\mathrm{OC}$ concentrations were measured using thermal optical analysis of snow and ice surface samples collected from glacier and mountain valleys in northern Pakistan in summer, autumn, and winter. The samples contained high concentrations of $\mathrm{BC}, \mathrm{OC}$, and dust in low-elevation glaciers and surface snow in mountain valleys. The samples from Sost contained the highest average concentration of $\mathrm{BC}$ in mountain valley snow (winter) and those from Kalam the lowest, probably due to the impact of snow age and an increased concentration of black carbon and dust (the Sost samples were aged snow, and Kalam samples were fresh snow). The average concentration of BC in surface samples from the Sachin glacier was higher in autumn than in summer; the BC values in summer snow samples collected from the Sachin and Gulkin glaciers (aged snow from the glacier surface) were much higher than those in ice. The average $\mathrm{BC}$ concentration in summer samples collected from glaciers was $2130 \pm 1560 \mathrm{ng} \mathrm{g}^{-1}$ and that in autumn samples $2883 \pm 3439 \mathrm{ng} \mathrm{g}^{-1}$. The average concentration of OC was $1839 \pm 1108 \mathrm{ng} \mathrm{g}^{-1}$ in summer samples, $1423 \pm 208 \mathrm{ng} \mathrm{g}^{-1}$ in autumn samples, and $1342 \pm 672 \mathrm{ng} \mathrm{g}^{-1}$ in winter sam- ples, with the highest variability in summer samples. The individual lowest BC $\left(82 \mathrm{ng} \mathrm{g}^{-1}\right)$ and OC $\left(129 \mathrm{ng} \mathrm{g}^{-1}\right)$ concentrations were observed in summer samples collected from the Gulkin and Sachin glaciers, respectively. Dust and other pollutants were clearly visible on aged snow and ice surfaces; the results indicate considerable enrichment during ageing. The pollutant concentrations in our samples were relatively higher than those reported by others in earlier studies, which tended to focus on the accumulation area of glaciers (e.g., ice cores and snow pits), where enrichment influences are less marked and measured values are likely to be lower, and on high-elevation areas, where the deposition of pollutants is expected to be lower. It is likely that pollutant concentrations were underestimated in these earlier studies, particularly when there was strong surface melting.

Snow albedo was calculated for winter samples using the SNICAR model with various combinations of $\mathrm{BC}$ and dust concentrations, three values for MAC, and a range of values for SZA (57-88.89 ${ }^{\circ}$ during daytime), with other parameters kept constant. BC was the major component responsible for albedo reduction; dust had little effect. The reduction by $\mathrm{BC}$ ranged from 2.8 to $32.5 \%$ during daytime, which 
is quite high, with albedo reduced to below 0.6. The reduction was greater for higher concentrations of $\mathrm{BC}$ and greater MAC. The reduction in $24 \mathrm{~h}$ average albedo ranged from $<0.07-2.9 \%$ for fresh snow samples and $<0.05-12.0 \%$ for aged snow. Changes in albedo contribute directly to radiative forcing: a decrease in albedo means that more radiation will be absorbed and the temperature will rise. The radiative forcing by $\mathrm{BC}$ was also higher than that caused by dust, indicating that $\mathrm{BC}$ was the dominant factor. The daytime albedo values in winter snow samples ranged from 0.39 to 0.82 with $\mathrm{BC}$ alone or $\mathrm{BC}$ plus dust and from 0.70 to 0.85 with dust alone; the corresponding radiative forcing was $3.93-43.44 \mathrm{~W} \mathrm{~m}^{-2}$ for BC alone, $4.01-43.45 \mathrm{~W} \mathrm{~m}^{-2}$ for BC and dust, and $0.16-2.08 \mathrm{~W} \mathrm{~m}^{-2}$ with dust alone. The radiative forcing calculated from the daily mean albedo reduction ranged from $0.1 \%$ for dust only at the low-pollutant site to $14.9 \%$ for BC at the high-pollutant site. The potential source regions of the pollutants deposited on glaciers and snow were identified using spatial variance in wind vector maps, emission inventories coupled with back air trajectories, and region-tagged chemical transport modeling. The wind vector maps identified central Asian and south Asian countries (such as Azerbaijan, Turkmenistan, Pakistan, Afghanistan, Syria, Iraq, and Turkey) as more important. The trajectory analysis coupled with emission inventories showed that air parcels reached northern Pakistan along three pathways: one from north Asia (Russia) via central Asia (Kazakhstan), one from western Asia (Cyprus and Syria) via central and southern Asia (Georgia), and one via India. The combination of the back-trajectory results and surface-wind direction analysis indicated that aerosols were significantly influenced by the long-range transport of pollutants from central and south Asia. The region-tagged chemical transport model indicated that Pakistan and south Asia were the main contributors of pollutants. Analysis based on the WRF-STEM model identified a significant contribution from Pakistan (up to $77 \%$ ) and south Asia (up to $71 \%$ ) at selected sites. Overall, the results indicate that central, south, and west Asia were the major sources of the pollutants detected at the sampling sites, with only a small contribution from east Asia.

The overall uncertainty of the $\mathrm{BC}$ and $\mathrm{OC}$ concentrations was estimated, taking into account the analytical precision of concentration measurements and the mass contribution from field blanks. The uncertainty in the $\mathrm{BC}$ and $\mathrm{OC}$ mass concentrations was calculated from the standard deviation of the field blanks, the experimentally determined analytical uncertainty, and the projected uncertainty associated with filter extraction. The major source of uncertainty was the effect of dust on the OC / BC measurements.

The albedo reduction from OC was not quantified. The contribution of OC to total visible absorption in the top snow layer is relatively small compared to that of $\mathrm{BC}$ and dust but has been shown to be significant $(\sim 19 \%$ of the total solar visible absorption) in several regions, including northeastern east Asia and western Canada (Yasunari et al., 2015). Snow grain size (snow aging) and snow texture were probably the main sources of uncertainty in the albedo reduction/radiative forcing calculations. The measured grain size was generally different from the effective optical grain size used in the SNICAR modeling, and although snow grain shape was measured, the results were not used in the online SNICAR albedo simulation model, which assumes a spherical shape for snow grains. This could slightly affect the results because the albedo of nonspherical grain is higher than the albedo of spherical grains (Chen et al., 2016).

The possible uncertainties on the modeling side relate to the use of $\mathrm{CO}$ as a tracer for light-absorbing particles to identify the source region. Uncertainties are also attributed to errors in the emission inventories, simulated meteorology, and removal processes built into the model. The physics and chemistry of removal of $\mathrm{BC}$ and $\mathrm{CO}$ differ, especially in the wet season. However, we analyzed the model during pre-monsoon and relatively dry periods when there should be a relatively good correlation in the transport of $\mathrm{CO}$ and BC. The global emission inventories used are unable to capture emissions at a local scale, and the contribution of local sources may also be underestimated by coarse-resolution models. High-resolution models and emission inventories at a local scale are required to capture local emissions.

Better constrained measurements will be required to obtain more robust results. High-resolution satellite imagery, high-resolution models, and continuous monitoring will help to reduce the present uncertainty.

Data availability. The data can be accessed at http: //shichang-kang.sklcs.ac.cn (Kang and Jie, 2018).

\section{The Supplement related to this article is available online at https://doi.org/10.5194/acp-18-4981-2018-supplement.}

Competing interests. The authors declare that they have no conflict of interest.

Acknowledgements. This study was supported by the National Natural Science Foundation of China (41630754, 41671067, 41721091), the Chinese Academy of Sciences (QYZDJ-SSWDQC039), the State Key Laboratory of Cryosphere Science (SKLCS-ZZ-2017), program funding to ICIMOD from the governments of Sweden and Norway, and ICIMOD core funds contributed by the governments of Afghanistan, Australia, Austria, Bangladesh, Bhutan, China, India, Myanmar, Nepal, Norway, Pakistan, Switzerland, and the United Kingdom. Acknowledgement is also due to A. Beatrice Murray for English editing of the manuscript. The authors would like to thank both the anonymous reviewers, whose reviews were extremely helpful in enhancing the quality of the manuscript. We would also like to convey our gratitude to the editor for the 
smooth handling of the manuscript.

Edited by: Robert McLaren

Reviewed by: two anonymous referees

\section{References}

Adhikary, B., Carmichael, G. R., Kulkarni, S., Wei, C., Tang, Y., D’Allura, A., Mena-Carrasco, M., Streets, D. G., Zhang, Q., Pierce, R. B., Al-Saadi, J. A., Emmons, L. K., Pfister, G. G., Avery, M. A., Barrick, J. D., Blake, D. R., Brune, W. H., Cohen, R. C., Dibb, J. E., Fried, A., Heikes, B. G., Huey, L. G., O’Sullivan, D. W., Sachse, G. W., Shetter, R. E., Singh, H. B., Campos, T. L., Cantrell, C. A., Flocke, F. M., Dunlea, E. J., Jimenez, J. L., Weinheimer, A. J., Crounse, J. D., Wennberg, P. O., Schauer, J. J., Stone, E. A., Jaffe, D. A., and Reidmiller, D. R.: A regional scale modeling analysis of aerosol and trace gas distributions over the eastern Pacific during the INTEX-B field campaign, Atmos. Chem. Phys., 10, 2091-2115, https://doi.org/10.5194/acp10-2091-2010, 2010.

Aoki, T., Kuchiki, K., Niwano, M., Kodama, Y., Hosaka, M., and Tanaka, T.: Physically based snow albedo model for calculating broadband albedos and the solar heating profile in snowpack for general circulation models, J. Geophys. Res. Atmos., 116, 1-22, https://doi.org/10.1029/2010JD015507, 2011.

Babu, S. S., Chaubey, J. P., Krishna Moorthy, K., Gogoi, M. M., Kompalli, S. K., Sreekanth, V., Bagare, S. P., Bhatt, B. C., Gaur, V. K., Prabhu, T. P., and Singh, N. S.: High altitude $(4520 \mathrm{mamsl})$ measurements of black carbon aerosols over western trans-Himalayas: Seasonal heterogeneity and source apportionment, J. Geophys. Res.-Atmos., 116, D24201, https://doi.org/10.1029/2011JD016722, 2011.

Bond, T. C., Bhardwaj, E., Dong, R., Jogani, R., Jung, S., Roden, C., Streets, D. G., and Trautmann, N. M.: Historical emissions of black and organic carbon aerosol from energy-related combustion, 1850-2000, Global Biogeochem. Cy., 21, GB2018, https://doi.org/10.1029/2006GB002840, 2007.

Boparai, P., Lee, J., and Bond, T. C.: Revisiting ThermalOptical Analyses of Carbonaceous Aerosol Using a Physical Model, Aerosol Sci. Tech., 42, 930-948, https://doi.org/10.1080/02786820802360690, 2008.

Cao, J. J., Lee, S. C., Ho, K. F., Zhang, X. Y., Zou, S. C., Fung, K., Chow, J. C., and Watson, J. G.: Characteristics of carbonaceous aerosol in Pearl River Delta Region, China during 2001 winter period, Atmos. Environ., 37, 1451-1460, https://doi.org/10.1016/S1352-2310(02)01002-6, 2003.

Chen, D., Wang, Y., McElroy, M. B., He, K., Yantosca, R. M., and Le Sager, P.: Regional CO pollution and export in China simulated by the high-resolution nested-grid GEOS-Chem model, Atmos. Chem. Phys., 9, 3825-3839, https://doi.org/10.5194/acp-93825-2009, 2009.

Cong, Z., Kawamura, K., Kang, S., Fu, P., River, G., River, Y., and River, Y.: Penetration of biomass-burning emissions from South Asia through the Himalayas?: new insights from, Scientific report, 5, 9580, https://doi.org/10.1038/srep09580, 2015.

Déry, S. J. and Brown, R. D.: Recent Northern Hemisphere snow cover extent trends and implications for the snow-albedo feedback, Geophys. Res. Lett., 34, L22504, https://doi.org/10.1029/2007GL031474, 2007.

Doherty, S. J., Grenfell, T. C., Forsström, S., Hegg, D. L., Brandt, R. E., and Warren, S. G.: Observed vertical redistribution of black carbon and other insoluble light-absorbing particles in melting snow, J. Geophys. Res.-Atmos., 118, 5553-5569, https://doi.org/10.1002/jgrd.50235, 2013.

Draxler, R. R. and Hess, G. D.: An Overview of the HYSPLIT_4 Modelling System for Trajectories, Dispersion, and Deposition, Aust. Meteorol. Mag., 47, 295-308, 1998.

Fitzgerald, W. F.: Clean hands, dirty hands: Clair Patterson and the aquatic biogeochemistry of mercury, in: Clean Hands: Clair Patterson's crusade against environmental lead contamination, 119137, 1999.

Flanner, M. G.: Arctic climate sensitivity to local black carbon, J. Geophys. Res.-Atmos., 118, 1840-1851, https://doi.org/10.1002/jgrd.50176, 2013.

Flanner, M. G. and Zender, C. S.: Linking snowpack microphysics and albedo evolution, J. Geophys. Res.-Atmos., 111, D12208, https://doi.org/10.1029/2005JD006834, 2006.

Flanner, M. G., Zender, C. S., Randerson, J. T., and Rasch, P. J.: Present-day climate forcing and response from black carbon in snow, J. Geophys. Res.-Atmos., 112, D11202, https://doi.org/10.1029/2006JD008003, 2007.

Flanner, M. G., Liu, X., Zhou, C., Penner, J. E., and Jiao, C.: Enhanced solar energy absorption by internally-mixed black carbon in snow grains, Atmos. Chem. Phys., 12, 4699-4721, https://doi.org/10.5194/acp-12-4699-2012, 2012.

Flanner, M. G., Zender, C. S., Hess, P. G., Mahowald, N. M., Painter, T. H., Ramanathan, V., and Rasch, P. J.: Springtime warming and reduced snow cover from carbonaceous particles, Atmos. Chem. Phys., 9, 2481-2497, https://doi.org/10.5194/acp9-2481-2009, 2009.

Gertler, C. G., Puppala, S. P., Panday, A., Stumm, D., and Shea, J.: Black carbon and the Himalayan cryosphere: A review, Atmos. Environ., 125, 404-417, https://doi.org/10.1016/j.atmosenv.2015.08.078, 2016.

Gillette, D. A., Blifford, I. H., and Fryrear, D. W.: Influence of wind velocity on size distributions of aerosols generated by wind erosion of soils, J. Geophys. Res., 79, 4068-4075, https://doi.org/10.1029/JC079i027p04068, 1974.

Grell, G. A., Peckham, S. E., Schmitz, R., McKeen, S. A., Frost, G., Skamarock, W. C., and Eder, B.: Fully coupled chemistry within the WRF model, Atmos. Environ., 39, 6957-6975, https://doi.org/10.1016/j.atmosenv.2005.04.027, 2005.

Gul, C., Kang, S., Ghauri, B., Haq, M., Muhammad, S., and Ali, S.: Using Landsat images to monitor changes in the snow-covered area of selected glaciers in northern Pakistan, J. Mt. Sci., 14, 2013-2027, https://doi.org/10.1007/s11629-016-4097-x, 2017.

Hansen, J. and Nazarenko, L.: Soot climate forcing via snow and ice albedos, P. Natl. Acad. Sci. USA, 101, 423-428, https://doi.org/10.1073/pnas.2237157100, 2004.

Hansen, J., Sato, M., Ruedy, R., Nazarenko, L., Lacis, A., Schmidt, G. A., Russell, G., Aleinov, I., Bauer, M., Bauer, S., Bell, N., Cairns, B., Canuto, V., Chandler, M., Cheng, Y., Del Genio, A., Faluvegi, G., Fleming, E., Friend, A., Hall, T., Jackman, C., Kelley, M., Kiang, N., Koch, D., Lean, J., Lerner, J., Lo, K., Menon, S., Miller, R., Minnis, P., Novakov, T., Oinas, V., Perlwitz, J., Perlwitz, J., Rind, D., Romanou, A., Shindell, D., Stone, P., Sun, 
S., Tausnev, N., Thresher, D., Wielicki, B., Wong, T., Yao, M., and Zhang, S.: Efficacy of climate forcings, J. Geophys. Res.Atmos., 110, D18104, https://doi.org/10.1029/2005jd005776, 2005.

He, C., Li, Q., Liou, K.-N., Takano, Y., Gu, Y., Qi, L., Mao, Y., and Leung, L. R.: Black carbon radiative forcing over the Tibetan Plateau, Geophys. Res. Lett., 41, 7806-7813, https://doi.org/10.1002/2014GL062191, 2014.

He, C., Takano, Y., Liou, K.-N., Yang, P., Li, Q., and Chen, F.: Impact of Snow Grain Shape and Black Carbon-Snow Internal Mixing on Snow Optical Properties: Parameterizations for Climate Models, J. Climate, 30, 1253-1268, https://doi.org/10.1175/JCLI-D-17-0300.1, 2017.

Horvath, H.: Atmospheric light absorption - A review, Atmos. Environ., 27A, 293-317, 1993.

Immerzeel, W. W., van Beek, L. P. H., and Bierkens, M. F. P.: Climate change will affect the Asian water towers, Science, 328, 1382-1385, https://doi.org/10.1126/science.1183188, 2010.

Jacobson, M. Z.: Climate response of fossil fuel and biofuel soot, accounting for soot's feedback to snow and sea ice albedo and emissivity, J. Geophys. Res., 109, D21201, https://doi.org/10.1029/2004JD004945, 2004.

Jaffe, D., Anderson, T., Covert, D., Kotchenruther, R., Trost, B., Danielson, J., Simpson, W., Blake, D., Harris, J., and Carmichael, G.: Transport of Asian air pollution to North America, Geophys. Res. Lett., 26, 711-714, 1999.

Kang, S. and Jie, Y.: BC-OC-dust in snow and glacier in Pakistan, available at: http://shichang-kang.sklcs.ac.cn, last access: 10 April 2018.

Kaspari, S., Painter, T. H., Gysel, M., Skiles, S. M., and Schwikowski, M.: Seasonal and elevational variations of black carbon and dust in snow and ice in the Solu-Khumbu, Nepal and estimated radiative forcings, Atmos. Chem. Phys., 14, 80898103, https://doi.org/10.5194/acp-14-8089-2014, 2014

Kaspari, S. D., Schwikowski, M., Gysel, M., Flanner, M. G., Kang, S., Hou, S., and Mayewski, P. A.: Recent increase in black carbon concentrations from a Mt. Everest ice core spanning 1860-2000 AD, Geophys. Res. Lett., 38, 11-16, https://doi.org/10.1029/2010GL046096, 2011.

LaChapelle, E. R.: Field guide to snow crystals, University of Washington Press, Seattie, Washington, USA, 1969

Lamarque, J. and Hess, P. G.: Model analysis of the temporal and geographical origin of the $\mathrm{CO}$ distribution during the TOPSE campaign, J. Geophys. Res., 108, 8354, https://doi.org/10.1029/2002JD002077, 2003.

Lamarque, J.-F., Bond, T. C., Eyring, V., Granier, C., Heil, A., Klimont, Z., Lee, D., Liousse, C., Mieville, A., Owen, B., Schultz, M. G., Shindell, D., Smith, S. J., Stehfest, E., Van Aardenne, J., Cooper, O. R., Kainuma, M., Mahowald, N., McConnell, J. R., Naik, V., Riahi, K., and van Vuuren, D. P.: Historical (1850-2000) gridded anthropogenic and biomass burning emissions of reactive gases and aerosols: methodology and application, Atmos. Chem. Phys., 10, 7017-7039, https://doi.org/10.5194/acp-10-7017-2010, 2010.

Li, X., Kang, S., He, X., Qu, B., Tripathee, L., Jing, Z., Paudyal, R., Li, Y., Zhang, Y., Yan, F., Li, G., and Li, C.: Lightabsorbing impurities accelerate glacier melt in the Central Tibetan Plateau, Sci. Total Environ., 587-588, 482-490, p. 587, https://doi.org/10.1016/j.scitotenv.2017.02.169, 2017.
Li, Y., Chen, J., Kang, S., Li, C., Qu, B., Tripathee, L., Yan, F., Zhang, Y., Guo, J., Gul, C., and Qin, X.: Impacts of black carbon and mineral dust on radiative forcing and glacier melting during summer in the Qilian Mountains, northeastern Tibetan Plateau, The Cryosphere Discuss., https://doi.org/10.5194/tc2016-32, 2016.

Liou, K. N., Takano, Y., He, C., Yang, P., Leung, L. R., Gu, Y., and Lee, W. L.: Stochastic parameterization for light absorption by internally mixed $\mathrm{BC} /$ dust in snow grains for application to climate models, J. Geophys. Res.-Atmos., 119, 7616-7632, https://doi.org/10.1002/2014JD021665, 2014.

Lu, Z., Streets, D. G., Zhang, Q., and Wang, S.: A novel backtrajectory analysis of the origin of black carbon transported to the Himalayas and Tibetan Plateau during 1996-2010, Geophys. Res. Lett., 39, L01809, https://doi.org/10.1029/2011GL049903, 2012.

Lüthi, Z. L., Škerlak, B., Kim, S.-W., Lauer, A., Mues, A., Rupakheti, M., and Kang, S.: Atmospheric brown clouds reach the Tibetan Plateau by crossing the Himalayas, Atmos. Chem. Phys., 15, 6007-6021, https://doi.org/10.5194/acp-156007-2015, 2015.

Mahowald, N., Albani, S., Kok, J. F., Engelstaeder, S., Scanza, R., Ward, D. S., and Flanner, M. G.: The size distribution of desert dust aerosols and its impact on the Earth system, Aeolian Res. 15, 53-71, https://doi.org/10.1016/j.aeolia.2013.09.002, 2014.

Ménégoz, M., Krinner, G., Balkanski, Y., Cozic, A., Boucher, O., and Ciais, P.: Boreal and temperate snow cover variations induced by black carbon emissions in the middle of the 21 st century, The Cryosphere, 7, 537-554, https://doi.org/10.5194/tc-7537-2013, 2013.

Ménégoz, M., Krinner, G., Balkanski, Y., Boucher, O., Cozic, A., Lim, S., Ginot, P., Laj, P., Gallée, H., Wagnon, P., Marinoni, A., and Jacobi, H. W.: Snow cover sensitivity to black carbon deposition in the Himalayas: from atmospheric and ice core measurements to regional climate simulations, Atmos. Chem. Phys., 14, 4237-4249, https://doi.org/10.5194/acp-14-4237-2014, 2014.

Menon, S., Koch, D., Beig, G., Sahu, S., Fasullo, J., and Orlikowski, D.: Black carbon aerosols and the third polar ice cap, Atmos. Chem. Phys., 10, 4559-4571, https://doi.org/10.5194/acp10-4559-2010, 2010.

Ming, J., Cachier, H., Xiao, C., Qin, D., Kang, S., Hou, S., and $\mathrm{Xu}$, J.: Black carbon record based on a shallow Himalayan ice core and its climatic implications, Atmos. Chem. Phys., 8, 13431352, https://doi.org/10.5194/acp-8-1343-2008, 2008.

Ming, J., Xiao, C., Cachier, H., Qin, D., Qin, X., Li, Z., and Pu, J.: Black Carbon (BC) in the snow of glaciers in west China and its potential effects on albedos, Atmos. Res., 92, 114-123, https://doi.org/10.1016/j.atmosres.2008.09.007, 2009.

Ming, J., Du, Z., Xiao, C., Xu, X., and Zhang, D.: Darkening of the mid-Himalaya glaciers since 2000 and the potential causes, Environ. Res. Lett., 7, 014021, https://doi.org/10.1088/17489326/7/1/014021, 2012.

Ming, J., Xiao, C., Du, Z., and Yang, X.: An overview of black carbon deposition in High Asia glaciers and its impacts on radiation balance, Adv. Water Resour., 55, 80-87, https://doi.org/10.1016/j.advwatres.2012.05.015, 2013.

Ming, J., Xiao, C., Wang, F., Li, Z., and Li, Y.: Grey Tienshan Urumqi Glacier No.1 and light-absorbing impurities, Environ. 
Sci. Pollut. R., 23, 9549-9558, https://doi.org/10.1007/s11356016-6182-7, 2016.

Muhammad, S. and Tian, L.: Changes in the ablation zones of glaciers in the western Himalaya and the Karakoram between 1972 and 2015, Remote Sens. Environ., 187, 505-512, https://doi.org/10.1016/j.rse.2016.10.034, 2016.

Nair, V. S., Babu, S. S., Moorthy, K. K.,Sharma, A. K., Marinoni, A., and Ajai: Black carbon aerosols over the Himalayas: Direct and surface albedo forcing, Tellus B, 65, 19738, https://doi.org/10.3402/tellusb.v65i0.19738, 2013.

Naoe, H., Hasegawa, S., Heintzenberg, J., Okada, K., Uchiyama, A., Zaizen, Y., Kobayashi, E., and Yamazaki, A.: State of mixture of atmospheric submicrometer black carbon particles and its effect on particulate light absorption, Atmos. Environ., 43, 1296-1301, https://doi.org/10.1016/j.atmosenv.2008.11.031, 2009.

Niu, H., Kang, S., Shi, X., Paudyal, R., He, Y., Li, G., and Wang, S.: Science of the Total Environment In-situ measurements of lightabsorbing impurities in snow of glacier on Mt. Yulong and implications for radiative forcing estimates, Sci. Total Environ., 581582, 848-856, https://doi.org/10.1016/j.scitotenv.2017.01.032, 2017.

Omar, A. H., Winker, D. M., Kittaka, C., Vaughan, M. A., Hu, Z. L. Y., Trepte, C. R., Rogers, R. R., Ferrare, R. A., and Lee, K. P., Kuehn, R. E., and Hostetler, C. A.: The CALIPSO Automated Aerosol Classification and Lidar Ratio Selection Algorithm, J. Atmos. Ocean. Tech., 26, 1994-2014, https://doi.org/10.1175/2009JTECHA1231.1, 2009.

Painter, T. H., Barrett, A. P., Landry, C. C., Neff, J. C., Cassidy, M. P., Lawrence, C. R., McBride, K. E., and Farmer, G. L.: Impact of disturbed desert soils on duration of mountain snow cover, Geophys. Res. Lett., 34, L12502, https://doi.org/10.1029/2007GL030284, 2007.

Painter, T. H., Deems, J. S., Belnap, J., Hamlet, A. F., Landry, C. C., and Udall, B.: Response of Colorado River runoff to dust radiative forcing in snow, P. Natl. Acad. Sci. USA, 107, 1712517130, https://doi.org/10.1073/pnas.0913139107, 2010.

Pandolfi, M., Ripoll, A., Querol, X., and Alastuey, A.: Climatology of aerosol optical properties and black carbon mass absorption cross section at a remote high-altitude site in the western Mediterranean Basin, Atmos. Chem. Phys., 14, 6443-6460, https://doi.org/10.5194/acp-14-6443-2014, 2014.

Park, M., Randel, W. J., Emmons, L. K., and Livesey, N. J.: Transport pathways of carbon monoxide in the Asian summer monsoon diagnosed from Model of Ozone and Related Tracers (MOZART), J. Geophys. Res., 114, D0830114, https://doi.org/10.1029/2008JD010621, 2009.

Qian, Y., Flanner, M. G., Leung, L. R., and Wang, W.: Sensitivity studies on the impacts of Tibetan Plateau snowpack pollution on the Asian hydrological cycle and monsoon climate, Atmos. Chem. Phys., 11, 1929-1948, https://doi.org/10.5194/acp11-1929-2011, 2011.

Qian, Y., Wang, H., Zhang, R., and Flanner, M. G.: A sensitivity study on modeling black carbon in snow and its radiative forcing over the Arctic and Northern China, Environ. Res. Lett., 9, 6, https://doi.org/10.1088/1748-9326/9/6/064001, 2014.

Qian, Y., Yasunari, T. J., Doherty, S. J., Flanner, M. G., Lau, W. K., Ming, J., Wang, H., Wang, M., Warren, S. G., and Zhang, R.: Light-absorbing Particles in Snow and Ice: Measurement and Modeling of Climatic and Hydrological Impact, Adv. At- mos. Sci., 32, 64-91, https://doi.org/10.1007/s00376-014-0010$0,2015$.

Qu, B., Ming, J., Kang, S.-C., Zhang, G.-S., Li, Y.-W., Li, C.-D., Zhao, S.-Y., Ji, Z.-M., and Cao, J.-J.: The decreasing albedo of the Zhadang glacier on western Nyainqentanglha and the role of light-absorbing impurities, Atmos. Chem. Phys., 14, 1111711128, https://doi.org/10.5194/acp-14-11117-2014, 2014.

Schmale, J., Flanner, M., Kang, S., Sprenger, M., Zhang, Q., Guo, J., Li, Y., Schwikowski, M., and Farinotti, D.: Modulation of snow reflectance and snowmelt from Central Asian glaciers by anthropogenic black carbon, Sci. Rep.-UK, 7, 40501, https://doi.org/10.1038/srep40501, 2017.

Venkataraman, C., Habib, G., Eiguren-Fernandez, A., Miguel, A. H., and Friedlander, S. K.: Residential Biofuels in South Asia: Carbonaceous Aerosol Emissions and Climate Impacts, Science, 307, 1454-1456, https://doi.org/10.1126/science.1104359, 2005.

Wang, J., He, X., Ye, B., and Yang, G.: Variations of Albedo on the Dongkemadi Glacier, Tang gula Range, Journal of Glaciology and Geocryology, 34, 21-28, 2012.

Wang, M., Xu, B., Zhao, H., Cao, J., Joswiak, D., Wu, G., and Lin, S.: The Influence of Dust on Quantitative Measurements of Black Carbon in Ice and Snow when Using a Thermal Optical Method, Aerosol Sci. Tech., 46, 60-69, https://doi.org/10.1080/02786826.2011.605815, 2012.

Wang, M., Xu, B., Cao, J., Tie, X., Wang, H., Zhang, R., Qian, Y., Rasch, P. J., Zhao, S., Wu, G., Zhao, H., Joswiak, D. R., Li, J., and Xie, Y.: Carbonaceous aerosols recorded in a southeastern Tibetan glacier: analysis of temporal variations and model estimates of sources and radiative forcing, Atmos. Chem. Phys., 15, 1191-1204, https://doi.org/10.5194/acp-15-1191-2015, 2015.

Wang, Q., Jacob, D. J., Fisher, J. A., Mao, J., Leibensperger, E. M., Carouge, C. C., Le Sager, P., Kondo, Y., Jimenez, J. L., Cubison, M. J., and Doherty, S. J.: Sources of carbonaceous aerosols and deposited black carbon in the Arctic in winter-spring: implications for radiative forcing, Atmos. Chem. Phys., 11, 1245312473, https://doi.org/10.5194/acp-11-12453-2011, 2011.

Wang, Y., Chung, A., and Paulson, S. E.: The effect of metal salts on quantification of elemental and organic carbon in diesel exhaust particles using thermal-optical evolved gas analysis, Atmos. Chem. Phys., 10, 11447-11457, https://doi.org/10.5194/acp-1011447-2010, 2010.

Wang, X., Pu, W., Ren, Y., Zhang, X., Zhang, X., Shi, J., Jin, H., Dai, M., and Chen, Q.: Observations and model simulations of snow albedo reduction in seasonal snow due to insoluble light-absorbing particles during 2014 Chinese survey, Atmos. Chem. Phys., 17, 2279-2296, https://doi.org/10.5194/acp17-2279-2017, 2017.

Warren, S. G.: Optical Properties of Snow (Paper 1R1505), Rev. Geophys. Space Ge., 20, 67-89, https://doi.org/10.1029/RG020i001p00067, 1982.

Warren, S. G. and Wiscombe, W. J.: Dirty snow after nuclear war, Nature, 313, 467-470, https://doi.org/10.1038/313467a0, 1985.

Wu, C., Huang, X. H. H., Ng, W. M., Griffith, S. M., and $\mathrm{Yu}$, J. Z.: Inter-comparison of NIOSH and IMPROVE protocols for OC and EC determination: implications for interprotocol data conversion, Atmos. Meas. Tech., 9, 4547-4560, https://doi.org/10.5194/amt-9-4547-2016, 2016.

Xu, B., Cao, J., Hansen, J., Yao, T., Joswia, D. R., Wang, N., Wu, G., Wang, M., Zhao, H., Yang, W., Liu, X., and He, J.: Black soot 
and the survival of Tibetan glaciers, P. Natl. Acad. Sci. USA, 106, 22114-22118, https://doi.org/10.1073/pnas.0910444106, 2009.

Xu, B., Cao, J., Joswiak, D. R., Liu, X., Zhao, H., and He, J.: Postdepositional enrichment of black soot in snow-pack and accelerated melting of Tibetan glaciers, Environ. Res. Lett., 7, 14022, https://doi.org/10.1088/1748-9326/7/1/014022, 2012.

Yang, S., Xu, B., Cao, J., Zender, C. S., and Wang, M.: Climate effect of black carbon aerosol in a Tibetan Plateau glacier, Atmos. Environ., 111, 71-78, https://doi.org/10.1016/j.atmosenv.2015.03.016, 2015.

Yao, T., Thompson, L., Yang, W., Yu, W., Gao, Y., Guo, X., Yang, X., Duan, K., Zhao, H., and Xu, B.: Different glacier status with atmospheric circulations in Tibetan Plateau and surroundings, Nat. Clim. Change, 2, 663-667, 2012.

Yasunari, T. J., Bonasoni, P., Laj, P., Fujita, K., Vuillermoz, E., Marinoni, A., Cristofanelli, P., Duchi, R., Tartari, G., and Lau, K.-M.: Estimated impact of black carbon deposition during premonsoon season from Nepal Climate Observatory - Pyramid data and snow albedo changes over Himalayan glaciers, Atmos. Chem. Phys., 10, 6603-6615, https://doi.org/10.5194/acp10-6603-2010, 2010.
Yasunari, T. J., Koster, R. D., Lau, W. K. M., and Kim, K.: Impact of snow darkening via dust, black carbon, and organic carbon on boreal spring climate in the Earth system, J. Geophys. Res.-Atmos., 120, 5485-5503, https://doi.org/10.1002/2014JD022977, 2015.

Zhang, G., Kang, S., Fujita, K., Huintjes, E., Xu, J., Yamazaki, T., Haginoya, S., Wei, Y., Scherer, D., Schneider, C., and Yao, T.: Energy and mass balance of Zhadang glacier surface, central Tibetan Plateau, J. Glaciol., 59, 137-148, https://doi.org/10.3189/2013JoG12J152, 2013.

Zhang, Y., Hirabayashi, Y., Liu, Q., and Liu, S.: Glacier runoff and its impact in a highly glacierized catchment in the southeastern Tibetan Plateau: Past and future trends, J. Glaciol., 61, 713-730, https://doi.org/10.3189/2015JoG14J188, 2015.

Zhang, Y., Kang, S., Xu, M., Sprenger, M., Gao, T., Cong, Z., Li, C., Guo, J., Xu, Z., Li, Y., Li, G., Li, X., Liu, Y., and Han, H.: Light-absorbing impurities on Keqikaer Glacier in western Tien Shan?: concentrations and potential impact on albedo reduction, Sciences in Cold and Arid Regions, 9, https://doi.org/10.3724/SP.J.1226.2017.00097, 2017. 